\title{
Przetrwale moreny czołowe na NW skłonie Garbu Lubawskiego - struktura i mechanizmy formowania
}

\author{
Palimpsest terminal moraines in NW part of Lubawa Upland - structure and mechanisms \\ of formation
}

\author{
Karol Tylmann', Wojciech Wysota ${ }^{1}$, Jan A. Piotrowski \\ ${ }^{1}$ Katedra Geologii i Hydrogeologii, Uniwersytet Mikołaja Kopernika,Toruń, k.tylmann@gmail.com \\ ${ }^{2}$ Department of Geoscience, Aarhus University, Dania
}

\begin{abstract}
Zarys treści: W artykule przedstawiono wyniki badań litofacjalnych i strukturalnych osadów budujących przetrwałe moreny czołowe na NW skłonie Garbu Lubawskiego. Uzyskane rezultaty wskazują na złożoną genezę badanych wzgórz oraz na wyraźne cechy świadczące o ich przetrwałości. Zaproponowano modele genetyczne dla analizowanych form, prezentujące główne etapy ich formowania oraz mechanizmy sprzyjające ich zachowaniu w strefie subglacjalnej. Analiza budowy badanych form sugeruje ich ,palimpsestowy” charakter oraz możliwy wpływ wieloletniej zmarzliny na procesy przetrwania wzgórz pod ostatnim lądolodem skandynawskim.
\end{abstract}

Słowa kluczowe: przetrwałość rzeźby glacjalnej, procesy subglacjalne, moreny czołowe, Garb Lubawski

\begin{abstract}
This article presents the results of lithofacies and structural studies of deposits in the palimpsest terminal moraines on the NW slope of Lubawa Upland. The results document a complex origin of these hills and some distinct features suggesting their palimpsest nature. We propose genetic models highlighting the main stages of their formation as well as the mechanisms of their preservation in the subglacial system. The inner structure of the hills suggests a crucial role of permafrost in preservation protecting the hills from erosion under the last Scandinavian Ice Sheet.
\end{abstract}

Key words: preservation of glacial landforms, subglacial processes, terminal moraines, Lubawa Upland

\section{Wstęp}

Zjawisko przetrwania form rzeźby pod lądolodami w stanie niezmienionym lub też nieznacznie zmodyfikowanym przez procesy subglacjalne było dokumentowane zarówno na obszarach zlodowaceń plejstoceńskich (m.in. Kleman 1992, Kleman, Borgström 1994, Hätterstrand, Stroeven 2002, Davis i in. 2006, Molewski 2007, Roman 2012), jak i w strefach zlodowacenia współczesnego (m.in. Jonsson 1983, Bergsma i in. 1984). Na terenach pokrytych obecnie przez lodowce najbardziej przekonującym dowodem konserwowania ich podłoża są wyłaniających się spod lodu mchy i porosty lub grunty strukturalne i gleby, które przetrwały w strefie subglacjalnej w niemal nienaruszonym stanie (Goldthwait 1960). Na obszarach ostatniego zlodowacenia plejstoceńskiego identyfikowano natomiast formy rzeźby glacjalnej lub peryglacjalnej uformowane niewątpliwie przed ostatnią transgresją lądolodu, co wskazuje na ich przetrwanie w niezmienionym stanie pod lądolodem skandynawskim (Kleman 1992) lub laurentyjskim (Davis i in. 2006).

W artykule przedstawiono wyniki badań sedymentologicznych, które wskazują na występowanie przetrwałych moren czołowych na NW skłonie Garbu Lubawskiego. Jak dotąd zjawisko konserwowania form rzeźby pod lądolodami utożsamiano głównie z zimnym reżimem termicznym lodu bazalnego, z którym związane jest przymarznięcie stopy lądolodu do podłoża, brak wody w systemie 
subglacjalnym oraz zanik lub też znaczne ograniczenie aktywności procesów erozji i deformacji subglacjalnej (Kleman 1994). Warunki tego typu panowały głównie w centralnej części dawnych lądolodów, gdzie klimat sprzyjał rozwojowi zimnego reżimu termicznego lądolodu (Kleman 1992, Kleman, Borgström 1994). Strefy te charakteryzują się występowaniem systemu suchego podłoża (ang. dry bed system) w opozycji do marginalnego systemu roztopowego (ang. marginal meltwater system) charakterystycznego dla stref bliższych krawędzi lodowej, gdzie aktywność procesów morfotwórczych w strefie subglacjalnej powinna być znacznie większa (Kleman 1994).

Obszar, na którym prowadzono badania, był zlokalizowany w brzeżnej części ostatniego lądolodu skandy- nawskiego, a mimo to występują tu formy morenowe, których budowa wskazuje na możliwość ich przetrwania w warunkach subglacjalnych. Głównym celem artykułu jest przedstawienie modeli formowania analizowanych wzgórz morenowych oraz identyfikacja czynników sprzyjających konserwacji rzeźby NW skłonu Garbu Lubawskiego pod ostatnim lądolodem skandynawskim.

\section{Obszar badań}

Garb Lubawski jest obszarem szczególnie wyróżniającym się w północnej Polsce pod względem świeżości rzeźby glacjalnej. Charakteryzuje się on obecnością licznych wzgórz morenowych o stosunkowo dużych wysokościach

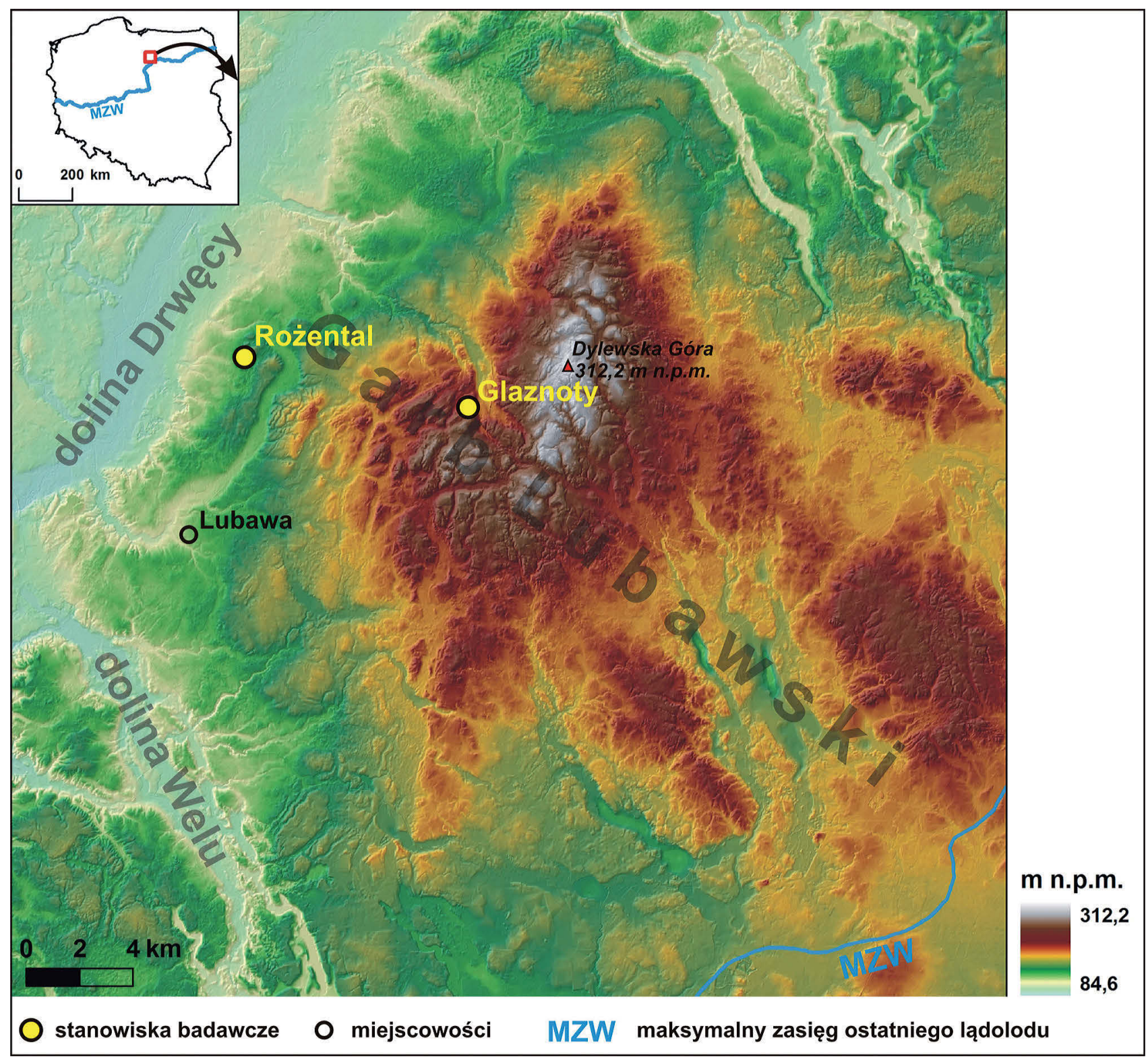

Ryc. 1. Lokalizacja stanowisk badawczych na tle cyfrowego modelu terenu Garbu Lubawskiego oraz maksymalnego zasięgu ostatniego lądolodu skandynawskiego (MZW)

Fig. 1. Location of the field sites against the digital terrain model of the Lubawa Upland and the maximum extent of the last Scandinavian Ice Sheet (MZW) 

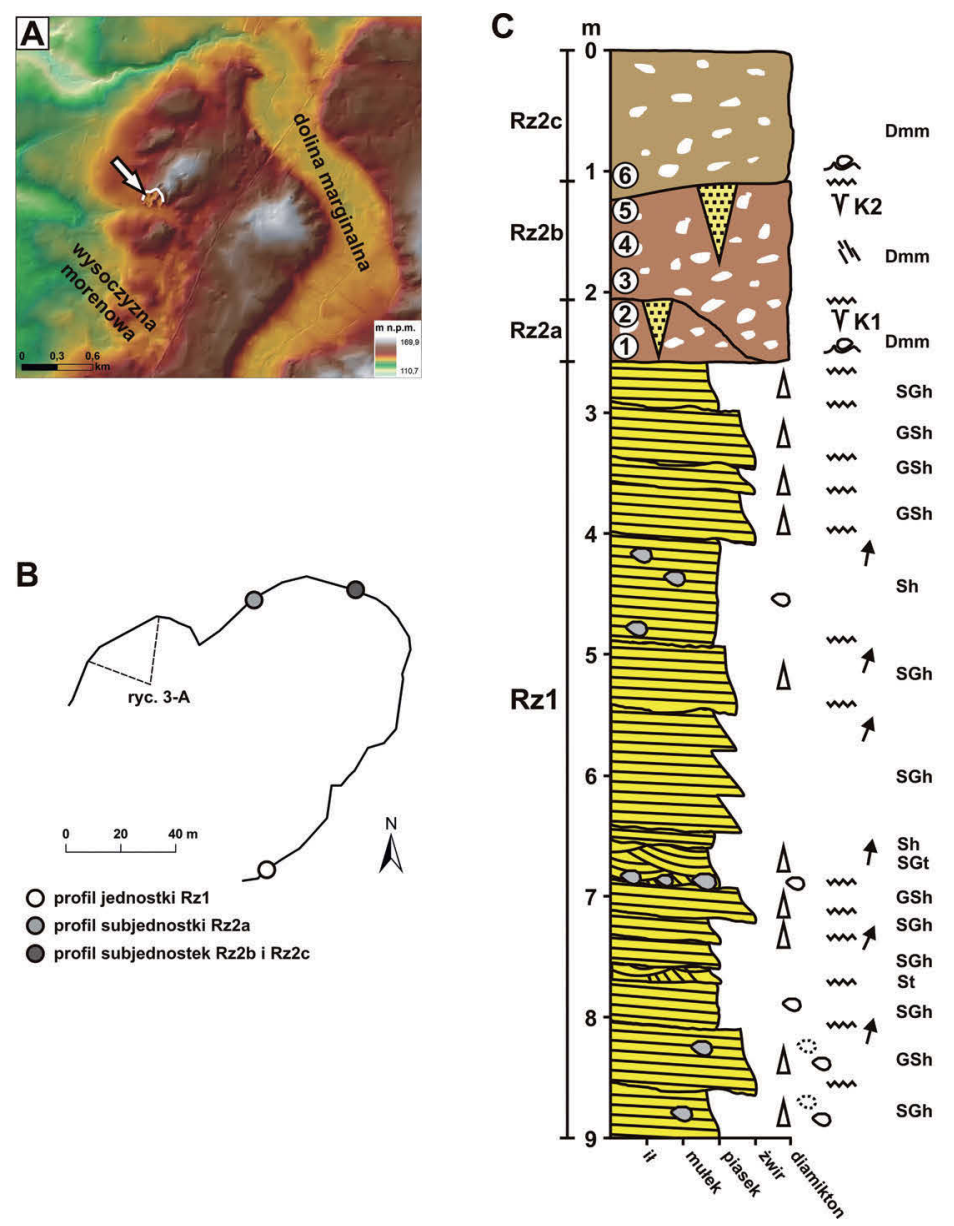

D
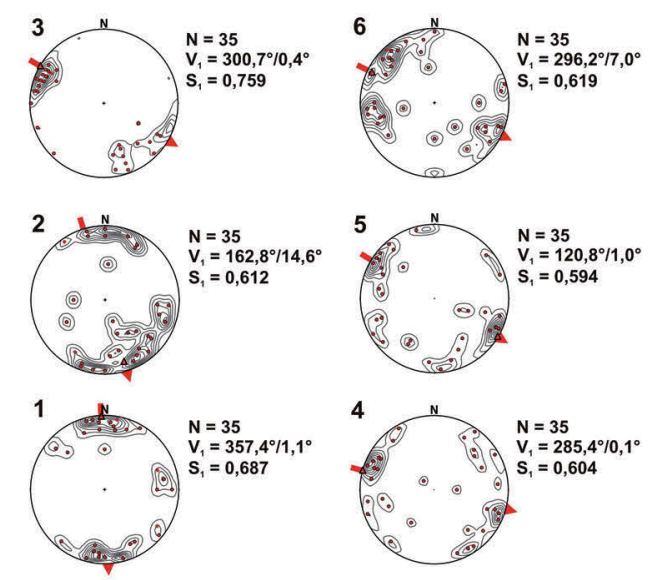

\section{Objaśnienia}

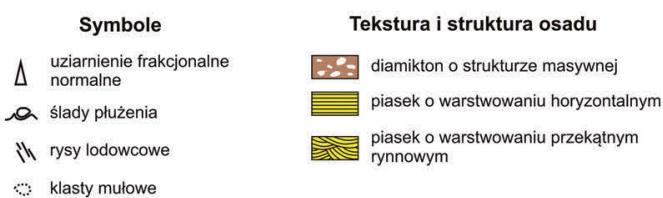

klasty żwirowe Diagram orientacji klastów

$\checkmark$ kliny mrozowe

mon kontakt erozyjny

K kierunki paleoprądów

(1) miejsca pomiarów orientaci

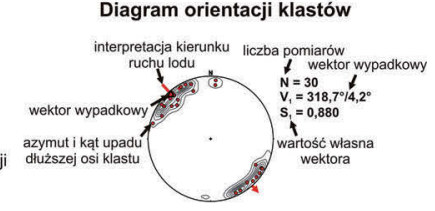

Ryc. 2. Stanowisko Rożental

A - lokalizacja badanego odsłonięcia (strzałka) oraz rzeźba terenu jego otoczenia, B - plan sytuacyjny odsłonięcia, C - syntetyczny profil litofacjalny głównych jednostek sedymentacyjnych, D - diagramy orientacji dłuższej osi klastów wraz z parametrami statystycznymi

Fig. 2. Rożental site

A - location of investigated gravel pit (arrow) and relief of its surroundings, B - plan view of the exposure, C - synthetic lithofacies profile of the main sedimentary units, D - till-fabric diagrams with statistical parameters

bezwzględnych jak na warunki Niżu Polskiego, z kulminacją Dylewskiej Góry (312,2 m n.p.m.). Garb Lubawski położony jest ponadto $\mathrm{w}$ sąsiedztwie maksymalnego zasięgu ostatniego lądolodu skandynawskiego, a większa jego część leży na zapleczu tego zasięgu (ryc. 1).

Stanowiska terenowe, w których prowadzono badania, są zlokalizowane w formach morenowych na północno-zachodnim skłonie Garbu Lubawskiego, na zachód od Dylewskiej Góry. Stanowisko Rożental jest położone na wysokości 145-148 m n.p.m., około 5,5 km na północ od miejscowości Lubawa i około $29 \mathrm{~km}$ na północny zachód od maksymalnego zasięgu ostatniego lądolodu (ryc. 1). Stanowisko Glaznoty jest zaś zlokalizowane na wysokości 223-226 m n.p.m., około 10 km na północny wschód od miejscowości Lubawa i około $25 \mathrm{~km}$ na północny zachód od maksymalnego zasięgu ostatniego lądolodu. Znajduje się ono w najwyżej położonej części Garbu Lubawskiego (Wzgórza Dylewskie), około 4 km na południowy zachód od Dylewskiej Góry (ryc. 1).

\section{Metody badań}

Sekwencje osadowe badanych stanowisk były kartowane przy użyciu standardowych technik analizy litofacjal-

Tabela 1. Kod litofacjalny według Mialla (1978) oraz Eylesa $\mathrm{i}$ in. (1982) zastosowany do opisu cech litologicznych badanych osadów

Table 1. Lithofacies code according to Miall (1978) and Eyles et al. (1983) used to describe lithological characteristics of investigated deposits

\begin{tabular}{c}
\hline Tekstura \\
\hline D - diamikton (osad wielofrakcyjny, słabo wysortowany) \\
$\mathrm{G}-$ żwir \\
$\mathrm{S}-$ piasek \\
$\mathrm{DS}-$ diamikton piaszczysty \\
$\mathrm{GS}-\dot{\mathrm{z} w i r}$ piaszczysty \\
$\mathrm{SG}-$ piasek żwirowy \\
\hline Struktura \\
\hline $\mathrm{h}-$ warstwowanie horyzontalne \\
$\mathrm{t}-$ warstwowanie przekątne rynnowe \\
$\mathrm{r}-$ przekątna laminacja riplemarkowa \\
$\mathrm{mm}-$ masywna, rozproszony szkielet ziarnowy \\
$\mathrm{ms}-$ warstwowa, rozproszony szkielet ziarnowy
\end{tabular}


nej oraz analizy strukturalnej (pomiary geometrii struktur deformacyjnych) stosowanych obecnie w badaniach osadów glacjalnych (m.in. Zieliński 1992, Wysota 2002, Terpiłowski 2003, Hubbard, Glasser 2005, Roman 2010). Cechy, na które zwrócono szczególną uwagę, to: skala i kształt wyróżnianych jednostek depozycyjnych, rodzaje kontaktów pomiędzy nimi, cechy kierunkowe oraz charakterystyka litofacjalna osadów. Cechy teksturalne oraz strukturalne osadów zostały opisane z zastosowaniem kodu litofacjalnego według Mialla (1978) oraz Eylesa i in. (1983) (tab. 1). Przyjęto następujące wartości miąższości dla określenia skali zestawów warstwowania i ławic: do $6 \mathrm{~cm}$ - mała skala, 6-30 cm - średnia skala, powyżej 30 cm - wielka skala (Zieliński 1992).
Orientacja dłuższej osi klastów w glinach morenowych (ang. till-fabric) była określana na podstawie pomiarów azymutu i kąta upadu co najmniej 30 głazików o długości od 1 do $10 \mathrm{~cm}$ i stosunku długości osi a:b $\geq$ 2:1 (Evans, Benn 2004). Taka liczba klastów dotyczy serii z jednego punktu pomiarowego. Wyniki przedstawiono na sferycznych diagramach punktowych i konturowych w projekcji na dolną półkulę równopowierzchniowej siatki Schmidta. Obliczono parametry statystyczne orientacji klastów, takie jak: wektor wypadkowy $\left(\mathrm{V}_{1}\right)$ oraz jego wartość własna $\left(\mathrm{S}_{1}\right)$ obrazująca siłę orientacji (Mark 1973) (ryc. 2).

Kierunki dawnego przepływu wody odtworzono na podstawie pomiarów azymutu upadu ławic osadów o warstwowaniu horyzontalnym. Wyniki pojedynczych
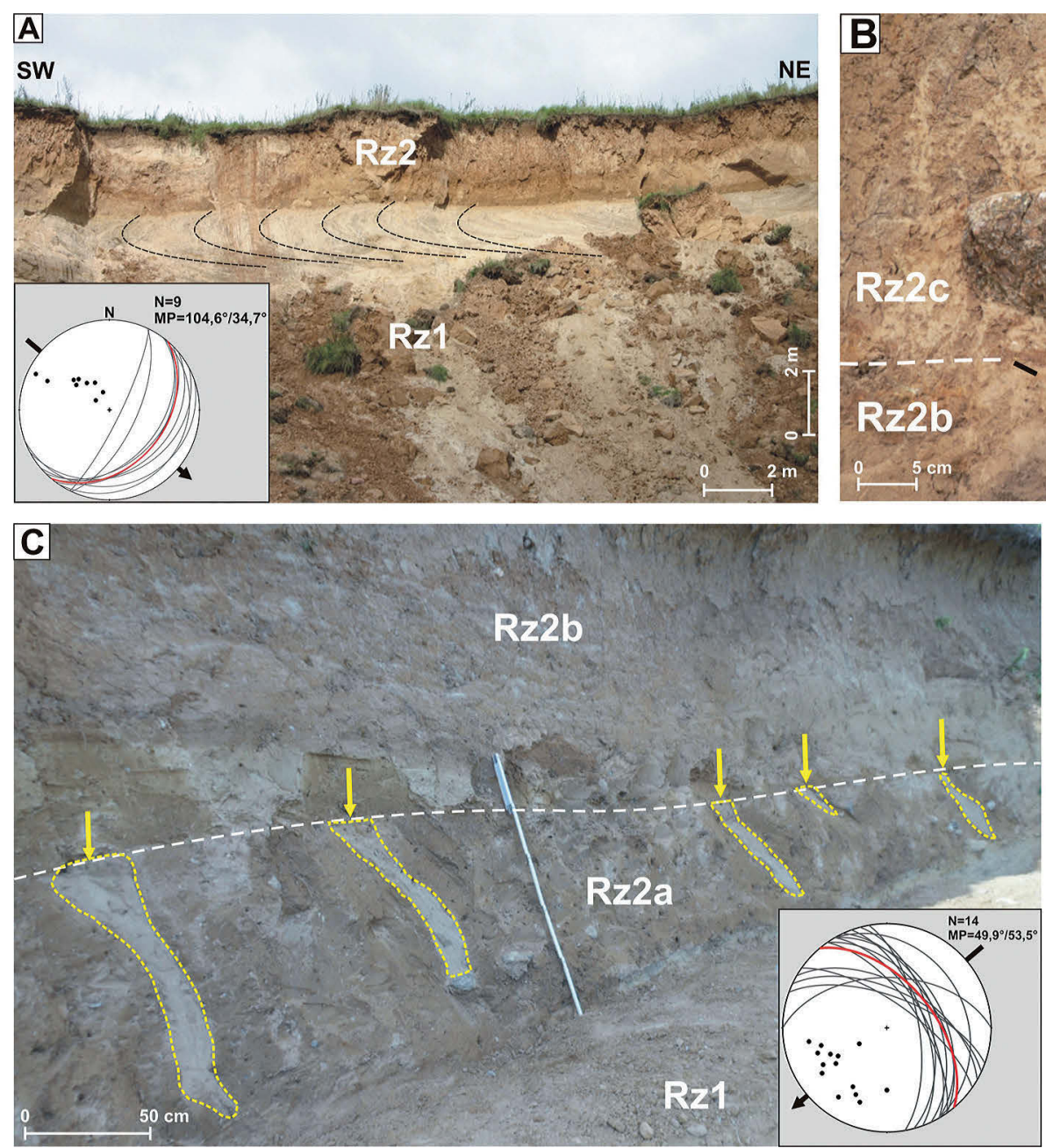
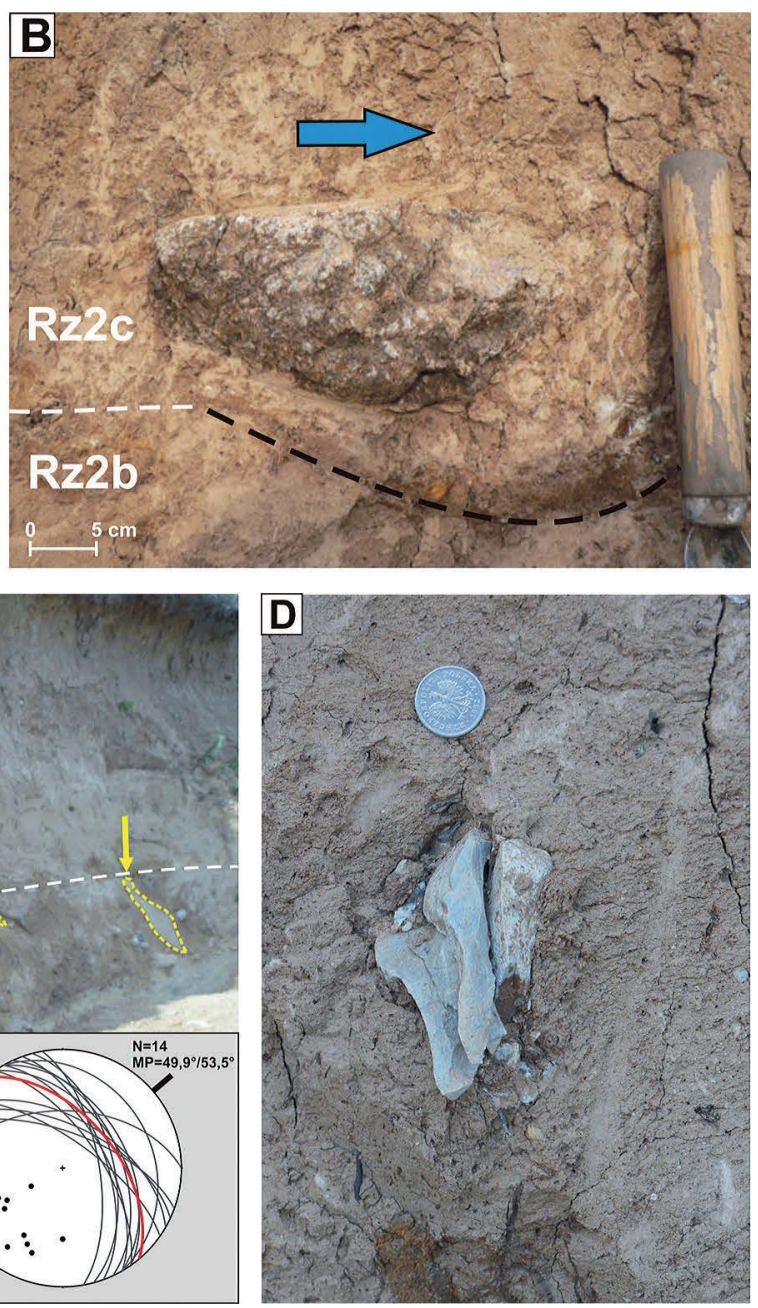

Ryc. 3. Cechy litologiczne osadów na stanowisku Rożental

A - ostry kontakt dwóch głównych jednostek sedymentacyjnych Rz1 (osady piaszczysto-żwirowe) i Rz2 (diamikton masywny), warstwy piaszczysto-żwirowe w górnej czę́ci jednostki Rz1 są wyraźnie odgięte, kierunki deformacji przedstawiono na diagramie, B - głaz o spłaszczonej górnej powierzchni zakorzeniony w spągu subjednostki Rz2c, czarna przerywana linia wskazuje na ślad płużenia, a niebieska strzałka pokazuje prawdopodobny kierunek ruchu lodu, C - poziom klinów mrozowych K1 rozwinięty w subjednostce Rz2a, żółte strzałki wskazują część zidentyfikowanych struktur mrozowych, na diagramie przedstawiono kierunek deformacji klinów mrozowych, D - jeden ze zwietrzałych klastów żwirowych, które powszechnie występują w górnej części gliny Rz2a w sąsiedztwie klinów mrozowych

Fig. 3. Lithological features of the deposits at Rożental site

A - sharp contact between two main sedimentary units Rz1 (sandy-gravely deposits) and Rz2 (massive diamicton), sandy-gravely layers in the upper part of Rz1 unit are clearly inclined, directions of deformation are shown on the diagram, B - clast with flattened upper surface embedded at the base of Rz2a sub-unit, the dark dotted line indicates a ploughing mark, blue arrow shows a possible direction of ice movement, $\mathrm{C}$ - layer of periglacial sand wedges in Rz2b sub-unit, yellow arrow indicates some of the identified wedges, deformation direction of the wedges is shown on the diagram, D - one of the weathered gravel clasts that are widespread within the upper part of Rz2b till, adjacent to periglacial sand wedges 
pomiarów przedstawiono w formie strzałek o odpowiedniej orientacji.

Pomiary struktur deformacyjnych dotyczyły zaburzonych warstw lub powierzchni nasunięć tworzących struktury glacitektoniczne (łuski) oraz zdeformowanych peryglacjalnych klinów piaszczystych. W odsłonięciu mierzono azymut i kąt upadu danej płaszczyzny (warstwa, powierzchnia nasunięcia lub struktura peryglacjalna). Wyniki przedstawiono w formie diagramów sferycznych wielkich kół obrazujących projekcję płaszczyzn i ich biegunów rzutowanych na dolną półkulę równopowierzchniowej siatki Schmidta (ryc. 3, 5). Obliczono średni kierunek nachylenia płaszczyzn (MP) oraz przedstawiono kierunek deformacji (naprężenia głównego) za pomocą strzałki (ryc. 3, 5).

\section{Stanowisko Rożental}

Stanowisko Rożental jest zlokalizowane na południowo-zachodnim skraju wydłużonego wzgórza morenowego o orientacji dłuższej osi NE-SW (ryc. 2A). Długość wzgórza wynosi około $800 \mathrm{~m}$, zaś jego szerokość ponad $300 \mathrm{~m}$. Jest ono położone w obrębie falistej wysoczyzny morenowej i wznosi się około $15 \mathrm{~m}$ ponad jej powierzchnię. Analizowana forma charakteryzuje się płaską powierzchnią szczytową, a jej maksymalna wysokość bezwzględna wynosi 165,5 m n.p.m.

W budowie geologicznej wzgórza morenowego wyróżniono dwie główne jednostki sedymentacyjne: piaszczysto-żwirową jednostkę Rz1 tworzącą rdzeń badanej formy oraz pokrywającą ją glinę morenową jednostki Rz2 (ryc. 2, 3). Osady odsłaniające się na stanowisku Rożental były przedmiotem wcześniejszych badań autorów w zakresie genezy występującej tu formy morenowej (Tylmann, Wysota 2011). Poniżej przedstawione zostaną wyniki nowszych badań oraz pełniejsza interpretacja mechanizmów formowania wzgórza w Rożentalu.

\section{Jednostki sedymentacyjne}

Jednostkę Rz1 buduje piaszczysto-żwirowa seria o miąższości przekraczającej $6 \mathrm{~m}$ (ryc. 2). Charakteryzuje się ona dominacją ławic piaszczysto-żwirowych i żwirowo-piaszczystych średniej i dużej skali o warstwowaniu horyzontalnym (SGh, GSh). W większość litofacji zaobserwowano cykle normalnego uziarnienia frakcjonalnego. Kontakty pomiędzy poszczególnymi warstwami mają wyraźnie erozyjny charakter (ryc. 2). W litofacjach o uziarnieniu piaszczystym i piaszczysto-żwirowym powszechnie występują ,,ponadwymiarowe” klasty żwirowe. W dolnej części analizowanej jednostki spotyka się również klasty mułowe o rozmiarach frakcji średniożwirowej. Wszystkie warstwy serii Rz1 są nieznacznie nachylone (do $10^{\circ}$ ) w kierunku NNE i NE.

Górna część jednostki Rz1 jest lokalnie zaburzona (ryc. 3A), o czym świadczą ugięcia ławic tworzące strukturę wstecznego fałdu leżącego (Tylmann, Wysota 2011). Zaburzone warstwy zapadają w kierunku południowo- -wschodnim pod maksymalnym kątem $80^{\circ}$. Wartość ich upadu maleje w kierunku spągu jednostki, gdzie na głębokości około $8 \mathrm{~m}$ od jej stropu deformacje całkowicie wygasają. Średni kierunek nachylenia ławic wynosi 104,6/34,7 $7^{\circ}$ (kierunek upadu/kąt upadu) (ryc. 3A). Powyżej przegubu fałdu, przy kontakcie jednostki Rz1 z pokrywającą ją warstwą gliny morenowej, zdeformowane ławice zapadają w kierunku przeciwnym (na NW). Tworzą one część skrzydła grzbietowego analizowanego fałdu, które jest ścięte przez leżącą wyżej warstwę gliny jednostki Rz2. Wielkość kompresji ławic piaszczysto-żwirowych w obrębie fałdu (ok. 6,3 m) oraz głębokość deformacji (ok. $8 \mathrm{~m}$ ) wskazują na niewielką wartość stopnia odkształcenia $(\varepsilon)$ rzędu około 0,8 .

Jednostka Rz2 pokrywa stoki wzgórza morenowego w Rożentalu. Tworzą ją trzy warstwy diamiktonu zaliczone do subjednostek Rz2a, Rz2b i Rz2c. Zalegają one powyżej osadów jednostki Rz1, a ich łączna miąższość wynosi około $2,5 \mathrm{~m}$ (ryc. 2, 3A). Wszystkie wyróżnione subjednostki są zbudowane $z$ masywnego diamiktonu o rozproszonym szkielecie ziarnowym (Dmm). Subjednostka Rz2a występuje jedynie w zachodniej części stanowiska i wyklinowuje się w kierunku północno-wschodnim. Pomiędzy subjednostkami diamiktonowymi dominują kontakty ostre o charakterze erozyjnym. W ich obrębie występują zakorzenione głazy o spłaszczonych górnych powierzchniach $\mathrm{z}$ rysami lodowcowymi oraz stowarzyszone z nimi ślady płużenia (ryc. 3B).

Diamikton jednostki Rz2 charakteryzuje się zróżnicowaną orientacją dłuższej osi klastów. W warstwie Rz2a (ryc. 2D, diagramy $1 \mathrm{i} 2$ ) wektory wypadkowe $\mathrm{V}_{1}$ wskazują na przeważające ukierunkowanie osi klastów na linii $\mathrm{N}-\mathrm{S}$ z lekkim odchyleniem zachodnim $\left(\mathrm{V}_{1}=357,4 / 1,1^{\circ}\right)$ W dolnej części warstwy oraz na linii NNW-SSE $\left(\mathrm{V}_{1}=162,8 / 14,6^{\circ}\right)$ w jej górnej części. Siła orientacji klastów jest stosunkowo wysoka w spągu gliny $\left(\mathrm{S}_{1}=0,687\right)$, ale obniża się wyraźnie w jej stropie $\left(\mathrm{S}_{1}=0,612\right)$. W diamiktonie Rz2b (ryc. 2D, diagramy 3, 4 i 5) kierunek wypadkowy orientacji klastów układa się na linii NW-SE, z lekkim odchyleniem zachodnim w środkowej części subjednostki, zaś wartości wektorów $\mathrm{V}_{1} \mathrm{w}$ punktach 3 , 4 i 5 wynoszą odpowiednio: $300,7 / 0,4^{\circ}, 285,4 / 0,1^{\circ}$ oraz $120,8 / 1,0^{\circ}$. Siła orientacji głazików jest bardzo dobra w spągu warstwy $\left(\mathrm{S}_{1}=0,759\right)$ i stopniowo maleje w górę profilu $\left(\mathrm{S}_{1}\right.$ wynosi $0,604 \mathrm{w}$ środkowej części warstwy i 0,594 w jej stropie). W warstwie Rz2c (ryc. 2D, diagram 6) wektor wypadkowy wskazuje na orientację większości klastów na linii NW-SE z lekkim odchyleniem zachod$\operatorname{nim}\left(V_{1}=296,2 / 7,0^{\circ}\right)$. Siła orientacji jest niska $\left(S_{1}=0,619\right)$.

\section{Struktury peryglacjalne}

W jednostce sedymentacyjnej Rz2 zostały udokumentowane struktury klinów mrozowych $\mathrm{z}$ wypełnieniem piaszczystym. Struktury te obok innych cech sedymentacyjnych osadów (tj. powierzchni niezgodności, ukierunkowania klastów) były podstawą podziału jednostki Rz2 na trzy odrębne warstwy diamiktonów (subjednostki 
sedymentacyjne): Rz2a, Rz2b i Rz2c. W warstwie Rz2a rozpoznano kliny, które tworzą wyraźny poziom kriostratygraficzny K1 (ryc. 3C). W subjednostce Rz2b udokumentowano jeden klin o stosunkowo dużych rozmiarach, który został oznaczony symbolem K2.

Rozpoznany w subjednostce Rz2a poziom kriostratygraficzny K1 tworzy 14 klinów piaszczystych o zróżnicowanych wymiarach i kształtach. Ich głębokość wynosi od 23 do $85 \mathrm{~cm}$, zaś szerokość górnych części waha się od 1,5 do $18 \mathrm{~cm}$. Odległość pomiędzy poszczególnymi strukturami wynosi od 0,5 do 3,4 m. Charakterystyczną cechą większości klinów jest ich pochylenie w kierunku południowo-wschodnim oraz deformacja górnych części. Wypadkowy kierunek nachylenia klinów wynosi $49,9^{\circ}$, zaś średni kąt upadu to $53,5^{\circ}$ (ryc. $3 \mathrm{C}$ ). Kliny poziomu K1 są wypełnione osadami drobnopiaszczystymi, w których zazwyczaj zaznacza się słabo widoczna laminacja pionowa. Pomiędzy badanymi klinami powszechnie występują spękane klasty żwirowe o różnych rozmiarach (ryc. 3D).

Stwierdzony w subjednostce Rz2b klin K2 ma głębokość $87 \mathrm{~cm}$, zaś jego szerokość wynosi maksymalnie 32 $\mathrm{cm}$. Struktura ta ma kształt typowego, zwężającego się ku dołowi klina, przy czym jego górna część jest wyraźnie odgięta i zapada w kierunku północno-zachodnim. Wielkość odkształcenia jest niewielka $(\varepsilon=\sim 0,9)$. Kontakt wypełnienia piaszczystego $\mathrm{z}$ diamiktonem, w którym tkwi klin K2, jest ostry. Również w górnej, odgiętej części struktury nie został on zatarty. Klin wypełniony jest osadem piaszczystym o wyraźnej pionowej laminacji.

\section{Interpretacja}

Osady jednostki Rz1 powstały w wyniku sedymentacji wodnolodowcowej. Ich wykształcenie litofacjalne świadczy o dominacji depozycji w rezultacie przepływów nadkrytycznych w formie płytkich zalewów warstwowych (Zieliński 1998). Kontakty erozyjne pomiędzy poszczególnymi ławicami sugerują dużą energię środowiska sedymentacji z licznymi epizodami erozji oraz etapami stosunkowo szybkiej sedymentacji. Cykle normalnego uziarnienia frakcjonalnego wskazują na wygaszanie energii przepływu podczas kolejnych etapów depozycji z zalewów warstwowych. Powszechne występowanie „ponadwymiarowych" klastów żwirowych oraz klastów mułowych w obrębie ławic piaszczystych może być związane $\mathrm{z}$ termoerozją zamarzniętych brzegów strumienia wodnolodowcowego i dostarczaniem materiału żwirowego oraz zamarzniętych klastów mułowych z zewnątrz do piaszczystej zawiesiny w obrębie strumienia (Mycielska-Dowgiałło 1998, Pisarska-Jamroży, Zieliński 2012).

Niewielkie nachylenie ławic osadów jednostki Rzl związane jest $\mathrm{z}$ depozycją osadów na powierzchni proksymalnej części stożka terminoglacjalnego (Zieliński, van Loon 1999, 2000), gdzie dynamika depozycji i erozji materiału osadowego uwarunkowana była głównie intensywnością ablacji czoła lądolodu. Kierunek nachylenia ławic świadczy o przepływie wody na NNE i NE, co mo- gło być związane z przebiegiem krawędzi lodowej i formowaniem płaskiego stożka napływowego o generalnym nachyleniu w kierunku NE. Jeżeli podczas depozycji analizowanej serii następowały okresy ekspozycji osadów na działanie czynników subaeralnych (np. w sezonach zimowych, kiedy zamierała ablacja), to można przypuszczać, że przynajmniej sezonowo miało miejsce przemarzanie gruntu. Niewykluczone, że proces ten mógł być bardziej trwały i przebiegać w warunkach wieloletniej zmarzliny, kiedy temperatura gruntu nie wzrastała powyżej $0^{\circ} \mathrm{C}$ co najmniej przez kolejne dwa lata (French 2007). W konsekwencji wraz ze wznawianiem przepływu wód roztopowych mogły być inicjowane procesy termoerozji.

Górna część piaszczysto-żwirowej serii Rzl została lokalnie zaburzona w wyniku deformacji subglacjalnej podłoża lądolodu. Świadczą o tym geometria fałdu, stopniowe wygaszanie zaburzeń w głąb profilu oraz niewielka rozbieżność pomiędzy kierunkami odkształcenia górnej części jednostki Rzl (NW-SE) a zrekonstruowanym kierunkiem ruchu lodu (NNW-SSE) (Tylmann, Wysota 2011). Zasięg pionowy deformacji (do $8 \mathrm{~m}$ w głąb jednostki Rz1) wskazuje na dużą miąższość (rzędu kilku metrów) strefy ścinania subglacjalnego. Jednocześnie stopień odkształcenia osadów jest bardzo niski $(\varepsilon=\sim 0,8)$, a pierwotne warstwowanie osadów piaszczysto-żwirowych nie zostało zatarte podczas deformacji. Świadczy to najprawdopodobniej o tym, że deformacji subglacjalnej mogły podlegać zamarznięte osady jednostki Rz1 w warunkach przymarznięcia stopy aktywnego lądolodu do podłoża. Transmisja naprężeń w głąb zamarzniętego podłoża oraz powolny proces jego odkształcania były charakterystyczne dla deformacji subglacjalnej tzw. „ciepłej” wieloletniej zmarzliny (ang. warm permafrost) o temperaturze nieznacznie niższej od punktu topnienia (Waller $i$ in. 2009). Deformacja subglacjalna zamarzniętego podłoża mogła powodować zarówno odkształcenia typu podatnego, jak i kruchego (Astakhov i in. 1996, Szuman i in. 2013). Proces deformacji częściowo sztywnego podłoża potwierdzałyby zatem również nieciągłe struktury deformacyjne (uskoki normalne oraz ścięcia) udokumentowane w górnej części serii piaszczysto-żwirowej (Gałązka i in. 2009, Tylmann, Wysota 2011).

Cechy sedymentacyjne analizowanych warstw glin morenowych wskazują na ich subglacjalną genezę. Gliny bazalne (subjednostki Rz2a, Rz2b i Rz2c) stanowia zapis sedymentologiczny odrębnych nasunięć lądolodu. Zostały one uformowane w następstwie kombinacji procesów subglacjalnych, głównie depozycji z odłożenia oraz płużenia. Zapisem tego typu procesów są zakorzenione głazy i związane $\mathrm{z}$ nimi ślady płużenia $\mathrm{w}$ glinach subjednostek Rz2a i Rz2c, rysy lodowcowe na górnej powierzchni głazów w glinie subjednostki Rz2b (por. Clark, Hansel 1989) oraz ostry i erozyjny kontakt pomiędzy poszczególnymi warstwami. Najbardziej znaczący udział w formowaniu gliny jednostki Rz2 miało stopniowe uwalnianie i przyrastanie bazalnego materiału morenowego w podeszwie aktywnego lądolodu (sensu Dreimanisa 1989) (Tylmann, Wysota 2011). Mogą to również potwierdzać masywna 
struktura diamiktonów oraz dobra orientacja klastów. Gliny te wykazują cechy tzw. subglacjalnych glin trakcyjnych (Evans i in. 2006).

Kliny mrozowe $\mathrm{z}$ wypełnieniem piaszczystym poziomu K1 oraz klin K2 powstały w wyniku zapełniania szczelin kontrakcji termicznej piaskiem eolicznym (Goździk 1973, Murton i in. 2000, Murton 2007). Rozmiar badanych klinów oraz struktura ich wypełnienia świadczy o wielokrotnym odnawianiu szczelin kontrakcyjnych, co jest charakterystyczne dla warunków wieloletniej zmarzliny. Ponadto cechy teksturalne osadu wypełniającego kliny, tj. uziarnienie i charakter powierzchni ziaren kwarcu (Tylmann, Wysota 2011), świadczą o udziale procesów eolicznych w jego transporcie. Analizowane struktury są więc klinami mrozowymi $\mathrm{z}$ pierwotnym wypełnieniem piaszczystym (ang. primary sand wedges), które mogą rozwijać się w tych samych regionach wieloletniej zmarzliny co inne kliny mrozowe (np. pseudomorfozy po klinach lodowych czy pseudomorfozy po klinach złożonych). Kierunek deformacji klinów poziomu K1 (zgodny z nachyleniem stoku wzgórza) sugeruje, że struktury te mogły podlegać ruchom masowym (np. soliflukcji), jakie objęły warstwę czynną wieloletniej zmarzliny rozwiniętą na powierzchni dawnego zbocza (Goździk 1967, Muton, French, 1993). Pomiary nachylenia warstwy Rz2a wskazują, że nachylenie dawnego stoku wynosiło co najmniej około $6^{\circ}$, co jest wartością wystarczającą do uruchomienia soliflukcji (French 2007). Deformacje struktur kriogenicznych obejmują całą warstwę Rz2a, co sugeruje, że miąższość warstwy czynnej wynosiła co najmniej $60 \mathrm{~cm}$. Poza tym ostry kontakt gliny Rz2a z piaszczysto-żwirowymi osadami podłoża oraz brak struktur świadczących o deformacjach grawitacyjnych w strefie tego kontaktu dowodzą, że rozwój warstwy czynnej ograniczał się jedynie do warstwy gliny. Spękane klasty żwirowe występujące w glinie Rz2a wskazują na jej wielokrotne zamarzanie i rozmarzanie, co potwierdza rozwój warstwy czynnej latem oraz jej zamarzanie zimą.

Deformacja górnej części klina K2 nastąpiła najprawdopodobniej w wyniku procesów ścinania subglacjalnego pod lądolodem, który odłożył glinę subjednostki Rz2c (Tylmann, Wysota 2011). Niewielkie odkształcenie górnej części klina $(\varepsilon=\sim 0,9)$ oraz ostre granice pomiędzy wypełnieniem a gliną otaczającą to wypełnienie świadczą o tym, że podłoże lądolodu było najprawdopodobniej deformowane w stanie zamarzniętym (Waller i in. 2012).

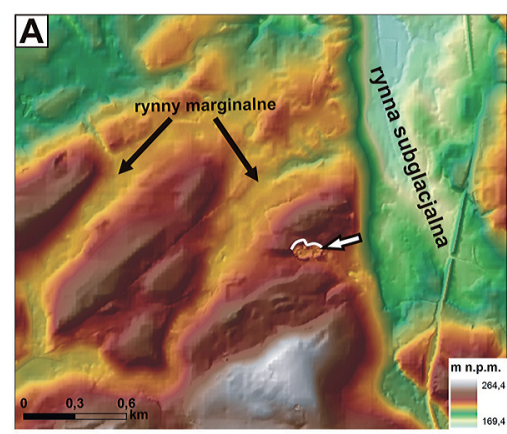

\section{c}

B

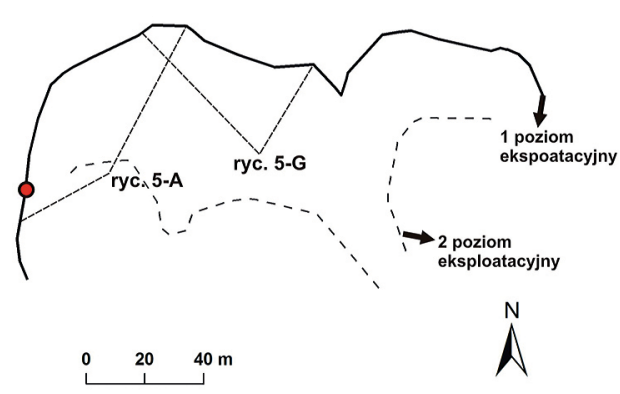

O lokalizacja profilu

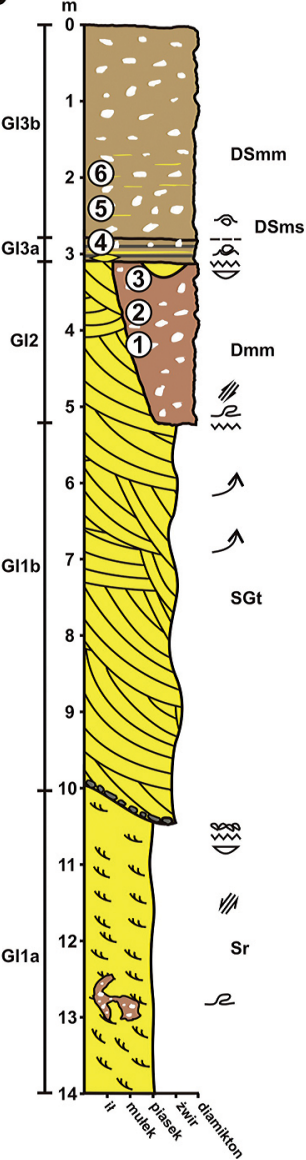

D
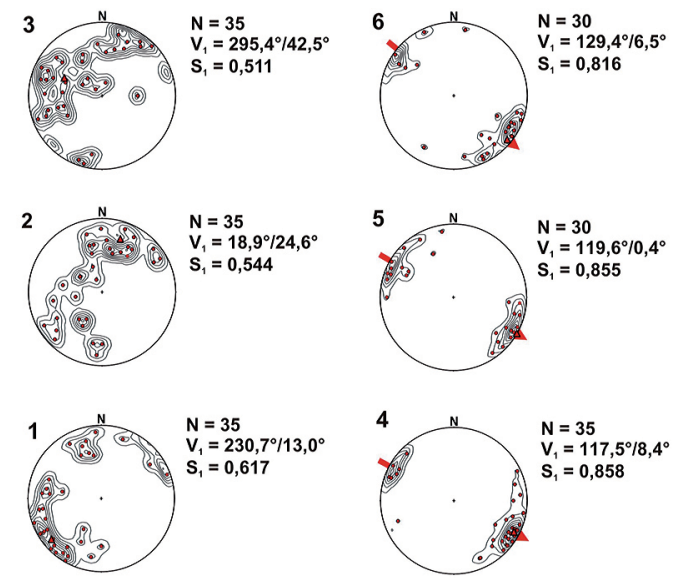

Objaśnienia

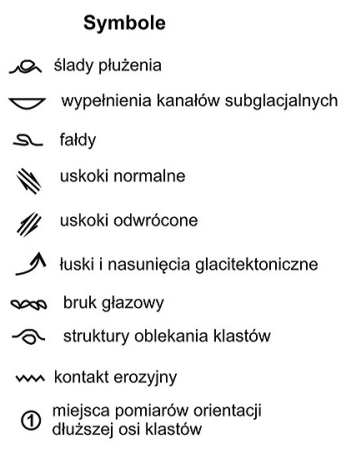

Tekstura i struktura osadu

$\because 9$ diamikton o strukturze masywnej

를 diamikton warstwowany piasek o warstwowaniu przekątnym rynnowym 世" piasek o przekatnej laminacji

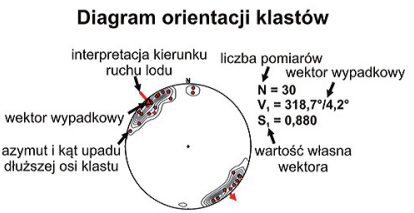

Ryc. 4. Stanowisko Glaznoty

A - lokalizacja badanego odsłonięcia (strzałka) oraz rzeźba terenu jego otoczenia, B - plan sytuacyjny odsłonięcia, C - profil litofacjalny głównych jednostek sedymentacyjnych, D - diagramy orientacji dłuższej osi klastów wraz z parametrami statystycznymi (objaśnienia symboli jak na ryc. 2)

Fig. 4. Glaznoty site

A - location of the investigated gravel pit (arrow) and relief of its surroundings, B - plan view of the exposure, C - lithofacies profile of the main sedimentary units, D - till-fabric diagrams with statistical parameters 

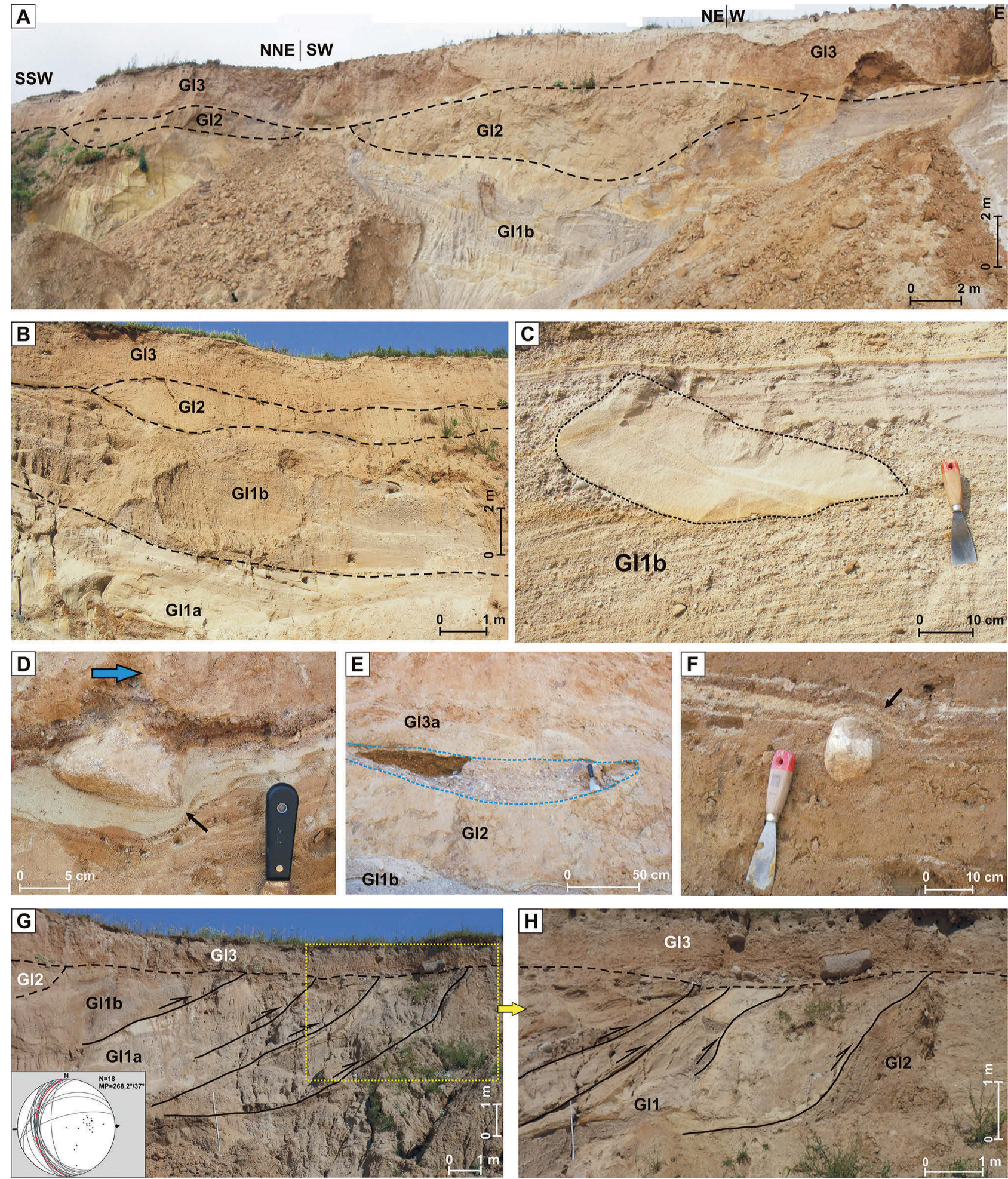

Ryc. 5. Cechy litologiczne osadów na stanowisku Glaznoty

A - sekwencja głównych jednostek sedymentacyjnych widocznych w odsłonięciu, B - następstwo jednostek i subjednostek sedymentacyjnych w zachodniej części wyrobiska, C - ostrokrawędzisty klast materiału piaszczystego tkwiący w górnej części osadów subjednostki Gl1b, D - przewarstwienie piaszczyste (czarna strzałka) występujące poniżej zapłużonego głazika w diamiktonie Gl3a (niebieska strzałka wskazuje prawdopodobny kierunek ruchu lodu), E - piaszczysta soczewka w dolnej części subjednostki Gl3a, F - przewarstwienie piaszczyste o niewielkiej miąższości (biała strzałka) oblekające od góry powierzchnię głazika w diamiktonie Gl3b, G-H - łuski glacitektoniczne w osadach jednostek Gl1 i Gl2, powyżej osadów zdeformowanych zalega niezgodnie warstwa diamiktonu Gl3 (strzałki oraz diagram pokazują kierunki nasunięć i deformacji)

Fig. 5. Lithological features of the sediments at Glaznoty site

A - succession of the main depositional units exposed in the section, B - succession of sedimentary units and sub-units in the western part of the exposure, C - angular clast of sand embedded within upper part of Gl1b sub-unit, D - sandy layer (black arrow) below a clast partly embedded in diamicton Gl3a (blue arrow shows a possible direction of ice movement), E - one of the sandy lenses in the lower part of sub-unit Gl3a, F - thin layer of sandy deposits (white arrow) draping the top of clast in a diamicton, $\mathrm{G}-\mathrm{H}$ - glacitectonic thrusts in units Gl1 and G12. Layer of diamicton Gl3 overlies discordantly the glacitectonized units (arrows on the diagram show directions of thrusting and deformation) 
Temperatura zamarzniętego gruntu była bliska punktowi topnienia (tzw. „ciepła” zmarzlina). Pod wpływem naprężenia ścinającego następowało powolne odkształcanie zamarzniętego podłoża wraz z nadległym lodem (Echelmeyer, Wang 1987).

\section{Stanowisko Glaznoty}

Stanowisko Glaznoty położone jest w południowej części wydłużonego wzgórza morenowego o orientacji dłuższej osi NE-SW (ryc. 4A). Długość tej formy wynosi około $580 \mathrm{~m}$, a jej maksymalna szerokość osiąga $330 \mathrm{~m}$. Bezwzględna wysokość analizowanego wzgórza wynosi 234 m n.p.m., zaś wysokość względna dochodzi do $24 \mathrm{~m}$ w stosunku do den otaczających je rynien marginalnych oraz $15 \mathrm{~m}$ w stosunku do powierzchni wysoczyzny morenowej. Charakterystyczną cechą wzgórza morenowego jest asymetria nachylenia zboczy, z bardziej stromym stokiem północno-zachodnim (ryc. 4A). Ściany odkrywki występują w dwóch poziomach eksploatacyjnych (ryc. 4B). Przedmiotem analizy były osady odsłaniające się w obrębie poziomu pierwszego.

\section{Jednostki sedymentacyjne}

Rdzeń formy buduje jednostka sedymentacyjna G11 (ryc. 5A). W jej obrębie stwierdzono osady piaszczyste oraz żwirowe o łącznej miąższości do $11 \mathrm{~m}$ (ryc. 4C). Dolna część jednostki Gl1 (subjednostka Gl1a) jest zbudowana z piasku drobnoziarnistego o przekątnej laminacji riplemarkowej (Sr), zaś w górnej (subjednostka Gl1b) występują słabo wysortowane osady piaszczysto-żwirowe o wielkoskalowym warstwowaniu przekątnym rynnowym (SGt) (ryc. 5B). W spągu subjednostki Gl1b stwierdzono lokalnie poziom niewielkich głazów, który podkreśla erozyjny charakter kontaktu z leżącymi niżej osadami subjednostki Gl1a (ryc. 4C). W górnej części subjednostki Gl1b udokumentowano ostrokrawędzisty klast piaszczysty o strukturze masywnej, o długości około $50 \mathrm{~cm}$ i szerokości $25 \mathrm{~cm}$. Kontakt pomiędzy klastem i otaczającymi go warstwowanymi osadami piaszczysto-żwirowymi jest ostry i nie wykazuje śladów deformacji (ryc. 5C).

Piaszczysto-żwirowa subjednostka Gl1b leży poniżej jednostki G12, którą tworzy nieciągła warstwa diamiktonu. Składają się na nią izolowane soczewy masywnego diamiktonu o rozproszonym szkielecie ziarnowym (Dmm), o miąższości do $6 \mathrm{~m}$ i o szerokości do $12 \mathrm{~m}$ (ryc. 4C, 5A). Cechuje je nieregularny przebieg dolnych granic oraz płaski charakter górnych powierzchni (ryc. 5B). Kontakt diamiktonu jednostki G12 z leżącymi niżej osadami piaszczysto-żwirowymi jest zazwyczaj erozyjny. Ukierunkowanie dłuższej osi klastów w diamiktonie jednostki G12 charakteryzuje się niską siłą orientacji (ryc. 4D, diagramy 1,2 i 3). Najwyższa wartość parametru $\mathrm{S}_{1}=0,617$ występuje w dolnej części jednostki, zaś w jej środkowej i górnej części wynosi ona odpowiednio 0,544 i 0,511. Orientacja wektora wypadkowego klastów w dolnej oraz w środkowej części diamiktonu jednostki G12 wskazuje na ich średnie ukierunkowanie NE-SW ( $\mathrm{V}_{1}$ wynosi odpowiednio $230,7 / 13,0^{\circ}$ oraz $18,9 / 24,6^{\circ}$ ), a w części górnej na linii WNW-ESE $\left(\mathrm{V}_{1}=295,4 / 42,5^{\circ}\right)$. Występują tu bardzo duże kąty upadu klastów, szczególnie w środkowej i górnej części jednostki Gl2 (ryc. 4D, diagramy 2 i 3).

Jednostkę G13 tworzy warstwa warstwowanego oraz masywnego diamiktonu piaszczystego (DSms i DSmm) o miąższości do $3 \mathrm{~m}$, która pokrywa powierzchnię wzgórza w Glaznotach (ryc. 4C, 5A). Na podstawie zróżnicowania litofacjalnego jednostki Gl3 wydzielono w jej obrębie subjednostki Gl3a i Gl3b. Subjednostka Gl3a, która występuje w spągu jednostki G13, jest zbudowana z piaszczystego diamiktonu o strukturze warstwowej. Jej miąższość wynosi około $20 \mathrm{~cm}$. Pokrywa ona ciągłą warstwą diamiktonowe soczewy jednostki Gl2 oraz piaszczysto-żwirowe osady jednostki Gl1. Jej kontakt z niżej leżącymi osadami jest wyraźnie erozyjny. W obrębie subjednostki Gl3a występują liczne przewarstwienia wysortowanego materiału piaszczystego o miąższości od kilku milimetrów do kilku centymetrów. Ich kontakt z otaczającym diamiktonem jest wyraźny i ostry. W przewarstwieniach piaszczystych w wielu miejscach zalegają zapłużone klasty żwirów, pod którymi stwierdzono ugięcia lamin piaszczystych ze strukturami dziobowymi (ang. sediment prows), świadczące o kierunku przemieszczania głazika (ryc. 5D). W spągu subjednostki Gl3a oraz na jej kontakcie z leżącymi niżej osadami powszechne są soczewki osadów piaszczystych i żwirowych o miąższości od 8 do $40 \mathrm{~cm}$ i o szerokości od 0,4 do 1,6 m. Mają one w większości kształt typowych soczewek o wypukłych dolnych oraz górnych powierzchniach, choć niektóre $\mathrm{z}$ nich charakteryzują się płaską górną powierzchnią (ryc. 5E). Wypełniające je osady piaszczysto-żwirowe zazwyczaj są warstwowane lub też mają strukturę masywną.

Subjednostka Gl3b pokrywa powierzchnię wzgórza i składa się z diamiktonu piaszczystego o strukturze masywnej i miąższości od 2 do 2,8 m. Dość powszechnie występują tu głazy o spłaszczonych górnych powierzchniach. Udokumentowano również przewarstwienia piaszczyste o niewielkiej miąższości, których część współkształtnie pokrywa klasty żwirów, tworząc charakterystyczne struktury oblekania (ryc. 5F). Kontakt subjednostki Gl3b z leżącym poniżej diamiktonem warstwowanym subjednostki Gl3a jest gradacyjny.

Wyniki pomiarów orientacji dłuższej osi klastów w jednostce Gl3 pokazują dobrą i bardzo dobrą orientację oraz konsekwentne ukierunkowanie wektorów wypadkowych na linii NW-SE we wszystkich seriach pomiarowych (ryc. 4C, 4D, diagramy 4, 5, 6). Wartości parametru $\mathrm{S}_{1}$ zawierają się $\mathrm{w}$ granicach od 0,816 do 0,858 , zaś wektory wypadkowe $\mathrm{V}_{1}$ charakteryzują się bardzo dużą zgodnością orientacji w całej warstwie i wskazują średni kierunek zapadania klastów na południowy wschód. Dominują niewielkie wartości kątów upadu głazików, które zazwyczaj nie przekraczają $10^{\circ}$. 


\section{Deformacje glacitektoniczne}

W obrębie osadów jednostek Gl1 i Gl2 rozpoznano wyraźne powierzchnie nieciągłości zapadające w kierunku zachodnim oraz północno-zachodnim pod kątem od 20 do $70^{\circ}$ (ryc. 5E, 5F). Kierunek wypadkowy upadu warstw w obrębie zdeformowanych pakietów wynosi $268,2 / 37^{\circ}$ (ryc. 5G). Zaburzone osady są pokryte warstwą diamiktonu piaszczystego Gl3, który zalega na nich niezgodnie (ryc. 5H).

\section{Interpretacja}

Przekątna laminacja riplemarkowa oraz drobnopiaszczyste uziarnienie osadów dolnej części jednostki Gll (subjednostka Gl1a) wskazują, że zostały one zdeponowane w środowisku o niskoenergetycznym przepływie w warunkach dolnego reżimu przepływu. Cechy strukturalne osadów jej górnego członu (subjednostka Gl1b) dowodzą ich depozycji w rezultacie przepływów o wyższej energii $\mathrm{w}$ warunkach dolnego ustroju prądu i $\mathrm{w}$ czasie rozwoju diun o krętych grzbietach (Zieliński 1998). Cała sekwencja osadów jest efektem sedymentacji wodnolodowcowej w strefie proglacjalnej, gdzie lokalne strefy o niskoenergetycznym przepływie (np. koryta drugorzędne) mogą współwystępować ze strefami głębokich i aktywnych koryt roztokowych, w których obrębie odbywała się sedymentacja bardziej gruboziarnistego materiału (Miall 1977). Wyraźnie erozyjny kontakt pomiędzy subjednostką Gllb a leżącymi niżej osadami subjednostki Glla wskazuje na wzrost energii transportu, rozmywanie osadów drobnopiaszczystych subjednostki Gl1a i zmianę stylu sedymentacji. Stosunkowo gruboziarnisty charakter osadów oraz granice erozyjne pomiędzy poszczególnymi zestawami warstwowania przekątnego rynnowego w subjednostce Gl1b sugerują transport o wysokiej energii z epizodami erozji i akumulacji (Miall 1983). Ich słaby stopień wysortowania świadczy o krótkim transporcie i depozycji w bliskim sąsiedztwie czoła lądolodu. Mogła ona następować $\mathrm{w}$ obrębie proksymalnej części równiny sandrowej lub na stożku terminoglacjalnym, na co wskazuje rzeźba terenu w rejonie stanowiska Glaznoty (położenie w proksymalnej części Garbu Lubawskiego).

O możliwości sezonowego przemarzania osadów subjednostki Gllb lub też o obecności w ich obrębie wieloletniej zmarzliny świadczy ostrokrawędzisty klast piaszczysty udokumentowany $\mathrm{w}$ górnej części subjednostki Gllb. Jego istnienie wskazuje na procesy termoerozji, jakie objęły zamarznięte brzegi koryta rzeki wodnolodowcowej, krótki transport i akumulację brył piaszczystych w stanie zamarzniętym (Mycielska-Dowgiałło 1998).

Diamikton jednostki Gl2 powstał w efekcie spływów kohezyjnych materiału morenowego przesyconego wodą w strefie marginalnej lądolodu (Lawson 1982). Świadczy o tym przede wszystkim wykształcenie jednostki Gl2 w formie izolowanych soczew oraz zróżnicowana orientacja klastów żwirowych. Brak ciągłości obocznej diamiktonu G12 oraz niekonsekwentne ukierunkowanie klastów żwirowych sugerują jego formowanie w następstwie spływów grawitacyjnych o zróżnicowanych, lokalnych ukierunkowaniach. Taką interpretację potwierdzają również wysokie wartości kąta upadu klastów żwirowych oraz niski stopień ich orientacji (Lawson 1979).

Powierzchnie nieciągłości zaobserwowane $\mathrm{w}$ jednostkach Gl1 i Gl2 dowodzą istnienia łusek glacitektonicznych. Wergencja tych struktur świadczy o działaniu głównych sił naciskających z kierunku zachodniego. Są one od góry ścięte erozyjnie i przykryte diamiktonem jednostki Gl3.

Cechy strukturalne jednostki Gl3 wskazują na jej subglacjalną genezę. Potwierdza to przede wszystkim jej ciągłość oboczna (pokrywa ona ciągłą warstwą o jednakowej miąższości całe wzgórze morenowe w Glaznotach), ostry kontakt z osadami leżącymi poniżej, silna orientacja klastów żwirowych oraz ich konsekwentne ukierunkowanie. Warstwa gliny bazalnej Gl3a powstała w efekcie stopniowego przyrastania materiału morenowego pod stopą lądolodu oraz odspajania podeszwy lądolodu od podłoża i depozycji wysortowanych osadów piaszczystych w środowisku wodnym. Dowodzą tego liczne przewarstwienia materiału wysortowanego występujące w diamiktonie, które są najprawdopodobniej zapisem procesów odspajania subglacjalnego (Evans i in. 2006). W warunkach wysokiego ciśnienia wód subglacjalnych, które było bliskie/ równe ciśnieniu lodu, następowało podnoszenie hydrauliczne stopy lądolodu oraz depozycja materiału wysortowanego w warstwach wody roztopowej na kontakcie lodu i podłoża (Piotrowski, Tulaczyk 1999). Kiedy ciśnienie wód subglacjalnych spadało poniżej poziomu, który równoważył nacisk lądolodu, lód bazalny odzyskiwał bezpośredni kontakt z podłożem i następowało uwalnianie materiału morenowego z poruszającej się stopy lądolodu, o czym świadczą ślady płużenia głazików (Clark, Hansel 1989). Kolejne podniesienie ciśnienia wód subglacjalnych powodowało kolejne odspojenie oraz utworzenie kolejnej warstwy materiału wysortowanego. Fluktuacje ciśnienia wód subglacjalnych doprowadziły najprawdopodobniej do uformowania warstwowej struktury analizowanej gliny i miały kluczowe znaczenie dla przebiegu procesów subglacjalnych (Wysota 2007).

Soczewki materiału wysortowanego (piaszczystego) występujące w spągowej części gliny Gl3a są zapisem skanalizowanego drenażu subglacjalnych wód roztopowych. Nieefektywny drenaż przez osady podłoża lądolodu powodował powstanie nadwyżki wód w systemie subglacjalnym, co z kolei skutkowało otwieraniem się kanałów subglacjalnych i spływem wód systemem skanalizowanym (Piotrowski i in. 2009). Wspomniane soczewki piaszczyste dokumentują drenaż kanałami wciętymi w osadowe podłoże lądolodu (kanały typu „N”), jak również wciętymi w podłoże i nadległy lód (Clarke 2005).

Glina subjednostki Gl3b była formowana głównie w wyniku procesów wytapiania bazalnego materiału morenowego pod stagnującym lub wolno poruszającym się lądolodem (Shaw 1979, 1982). Świadczą o tym diagno- 
styczne dla procesów wytapiania bazalnego struktury oblekania klastów, które występują powszechnie w analizowanej facji gliny. Obecność przewarstwień piaszczystych wskazuje na depozycję materiału wysortowanego w odspojeniach subglacjalnych. Mimo stagnowania mas lodowych podwyższone ciśnienie wód subglacjalnych mogło powodować epizodyczne odspajanie stopy lądolodu od podłoża (Munro-Stasiuk 2000).

\section{Modele formowania przetrwalych moren czołowych}

Interpretacja procesów depozycji i deformacji osadów na stanowiskach badawczych pozwoliła na opracowanie modeli genetycznych dla badanych wzgórz morenowych. Sekwencje osadowe świadczą o przetrwałości form marginalnych, które w różnym stopniu zostały zachowane pod ostatnim lądolodem skandynawskim.
A

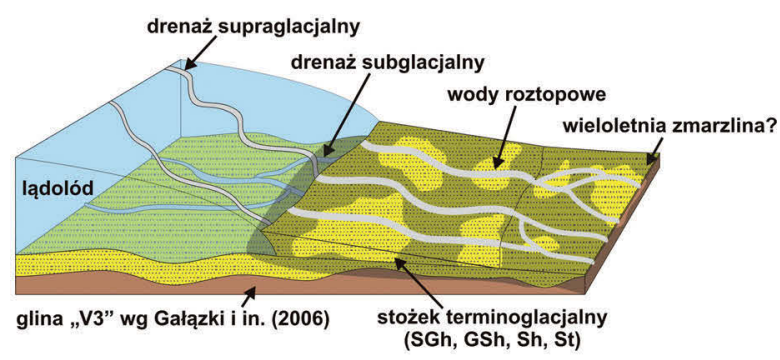

C

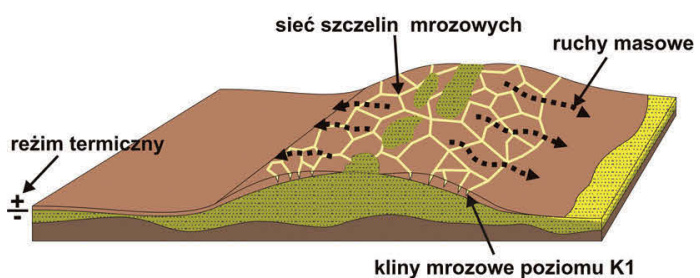

E

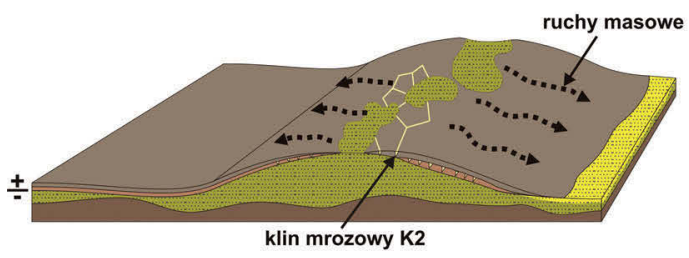

B

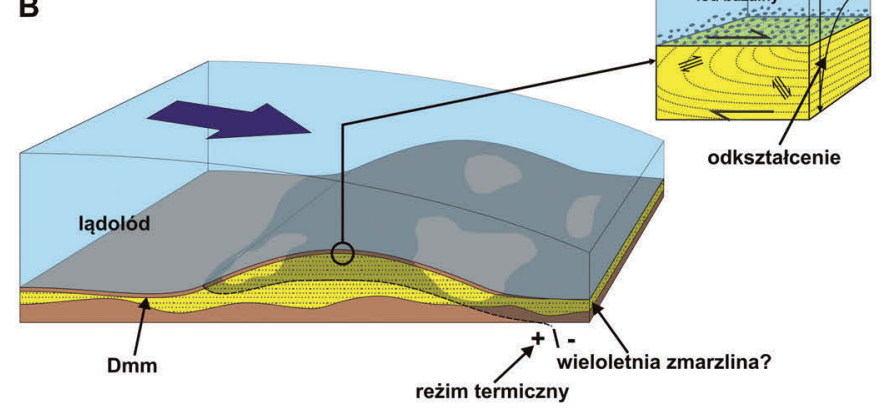

D
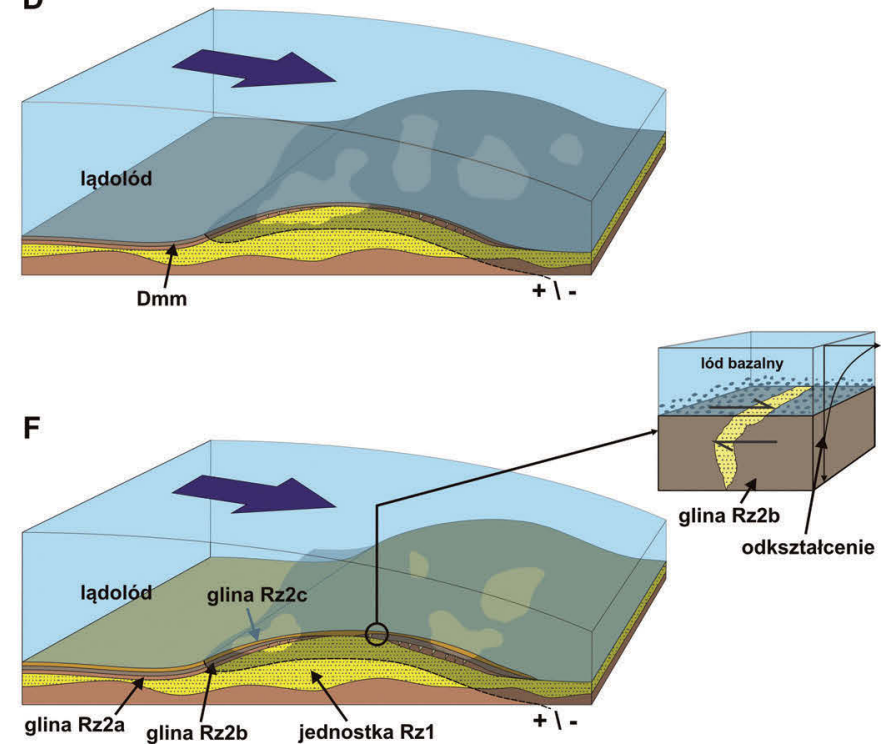

Ryc. 6. Model genetyczny sekwencji osadów i wzgórza w Rożentalu

A - depozycja osadów piaszczysto-żwirowych jednostki Rzl w środowisku fluwioglacjalnym (najprawdopodobniej w proksymalnej części stożka terminoglacjalnego, w bliskim sąsiedztwie czoła lądolodu), B - nasunięcie lądolodu, przekroczenie $i$ transformacja formy oraz deformacja subglacjalna osadów piaszczysto-żwirowych wraz z depozycją gliny bazalnej subjednostki Rz2a, C - recesja lądolodu, agradacja wieloletniej zmarzliny i tworzenie klinów piaszczystych, które podlegały dalszej deformacji w rezultacie ruchów masowych warstwy czynnej permafrostu, D - ponowne nasunięcie lądolodu oraz formowanie gliny bazalnej subjednostki Rz2b, E - recesja lądolodu i ponowny rozwój wieloletniej zmarzliny, powstawanie szczelin mrozowych i ich wypełnianie piaskiem eolicznym, F - ostatnie nasunięcie lądolodu, deformacja subglacjalna górnej części gliny subjednostki Rz2b i klina K2 oraz depozycja gliny subjednostki Rz2c

Fig. 6. Genetic model for sediments succession and landform formation at Rożental

A - deposition of sandy-gravely sediments of Rz1 unit within fluvioglacial environment (possibly on the proximal side of a terminoglacial fan, close to the ice margin), B - ice-sheet advance, overriding and transformation of the landform, subglacial deformation of sandy gravely deposits and deposition of Rz2a till, C - ice-sheet retreat, permafrost aggradation and formation of periglacial sand wedges which undergo further deformation due to mass movements of active layer, D - next ice-sheet advance and formation of till of sub-unit Rz2b, E - ice-sheet retreat and permafrost thickening, formation of frost cracks and its filling with aeolian sand, F - last ice-sheet advance, subglacial deformation of the upper part of till of sub-unit Rz2b and K2 wedge and deposition of till of sub-unit Rz2c 


\section{Stanowisko Rożental}

Dotychczasowe badania geologiczne na stanowisku Rożental dowodzą trzech nasunięć lądolodu zlodowacenia wisły, jakie miały miejsce po depozycji osadów jednostki Rz1 (gliny subjednostek Rz2a, Rz2b i Rz2c) (Tylmann, Wysota 2011, Tylmann 2014). Nasunięcia te były przedzielone okresami bez pokrywy lodowej, podczas których narastała wieloletnia zmarzlina i rozwijały się struktury peryglacjalne.

Osady jednostki Rz1 były akumulowane na stożku terminoglacjalnym w strefie kontaktu $\mathrm{z}$ czołem lądolodu (ryc. 6A). Wyniki datowania OSL tych osadów wskazują, że mogło to mieć miejsce w stadiale świecia ostatniego zlodowacenia (Tylmann 2014). Przypuszczalnie już wtedy powstała forma wypukła (wzgórze morenowe) zaznaczająca się w rzeźbie terenu. Deponowane osady ulegały sezonowemu przemarzaniu, a być może częściowo rozwinęła się w ich obrębie wieloletnia zmarzlina.

W kolejnym etapie forma ta została przekroczona przez lądolód, który nasunął się z kierunku północnego (ryc. 6B). Na obecnym etapie badań nie można precyzyjnie określić wieku tego nasunięcia. Podczas transgresji lądolód zaburzył górną część osadów jednostki Rz1 (powstanie fałdu leżącego i uskoków), które najprawdopodobniej pozostawały w zamarzniętym stanie. Po deformacji osadów piaszczysto-żwirowych nastąpiła częściowa degradacja wieloletniej zmarzliny pod lądolodem (por. Hughes 1992, Narloch i in. 2013). Następnie w warunkach ciepłego reżimu bazalnego oraz na kontakcie lodu i podłoża następowało przyrastanie gliny subglacjalnej Rz2a. Niewielka różnica pomiędzy wergencją zaburzonych warstw w osadach piaszczysto-żwirowych (NW$\mathrm{SE}$ ), a ukierunkowaniem dłuższej osi głazików w przykrywającej je glinie subjednostki Rz2a (NNW-SSE) sugeruje, że deformacje podłoża i uwalnianie materiału morenowego ze stopy lądolodu nie następowały równocześnie.

W kolejnym etapie na analizowanym obszarze nastąpiła recesja lądolodu oraz rozwój wieloletniej zmarzliny (ryc. 6C). W suchym klimacie pustyni arktycznej na eksponowanej powierzchni „wzgórza morenowego” powstały kliny z pierwotnym wypełnieniem piaszczystym (poziom K1), które później podlegały deformacji w następstwie powolnych ruchów masowych (soliflukcji). Ruchy te zachodziły na stokach formy morenowej w warstwie czynnej wieloletniej zmarzliny i spowodowały także częściową erozję gliny jednostki Rz2a.

Podczas kolejnego etapu rozwoju wzgórza w Rożentalu nastąpiło nasunięcie lądolodu z kierunku NW (ryc. 6D). Lądolód ponownie przekroczył tę formę i przykrył ją kolejną warstwą gliny - subjednostka Rz2b. Transgresja ta miała najprawdopodobniej miejsce w fazie poznańskiej stadiału głównego zlodowacenia wisły (Tylmann 2014). Po recesji lądolodu po raz kolejny rozwinęły się peryglacjalne kliny piaszczyste oraz wieloletnia zmarzlina (klin K2 w glinie subjednostki Rz2b) (ryc. 6E). Ostatnie nasunięcie lądolodu na tym obszarze nastąpiło również $\mathrm{z}$ kierunku NW (ryc. 6F). Wyniki datowania OSL piaszczyste- go wypełnienia klina K2 sugerują, że nasunięcie to mogło mieć miejsce w fazie pomorskiej stadiału głównego zlodowacenia wisły (Tylmann 2014). W następstwie subglacjalnych procesów ścinania doszło do odkształcenia stropu gliny subjednostki Rz2b oraz górnej części klina K2, a następnie uformowana została glina subjednostki Rz2c, która obecnie buduje powierzchnię terenu w rejonie badanego odsłonięcia.

Przedstawiony powyżej scenariusz dowodzi tego, że wzgórze w Rożentalu jest formą ,przejechaną” o starszych założeniach, stanowiącą część współczesnej, pagórkowatej wysoczyzny morenowej (Aber 1982, Roman 2010, 2012).

\section{Stanowisko Glaznoty}

W pierwszym etapie formowania wzgórza w Glaznotach w strefie proglacjalnej lądolodu następowała wodnolodowcowa akumulacja osadów piaszczysto-żwirowych oraz piaszczystych jednostki Gl1 w obrębie proksymalnej części stożka terminoglacjalnego (ryc. 7A). Osady te były deponowane w warunkach klimatu peryglacjalnego, w których być może lokalnie rozwijała się wieloletnia zmarzlina. Uzyskane wyniki datowania OSL osadów jednostki Gl1 sugerują, że depozycja tych osadów mogła mieć miejsce podczas recesji lądolodu stadiału warty zlodowaceń środkowopolskich (Tylmann 2014).

W późniejszym etapie związanym prawdopodobnie $\mathrm{z}$ transgresją lądolodu zlodowacenia wisły nastąpiło spiętrzenie zamarzniętych osadów na przedpolu lądolodu i powstanie pozytywnej formy terenu - moreny spiętrzonej (ryc. 7B). Główny nacisk czoła lądolodu działał z kierunku zachodniego i północno-zachodniego. Brzeżna część transgredującego lądolodu była przypuszczalnie przymarznięta do podłoża, co powodowało kumulację naprężeń kompresyjnych, piętrzenie osadów na przedpolu lądolodu i w konsekwencji formowanie łusek glacitektonicznych (van der Wateren 1985). Ponadto w tej części Garbu Lubawskiego przedpole ostatniego lądolodu skandynawskiego było najprawdopodobniej nachylone w kierunku jego czoła (Marks 1979), co dodatkowo wpływało na powstawanie naprężeń kompresyjnych. Potwierdzeniem tego rodzaju genezy jest również asymetria nachylenia zboczy wzgórza morenowego z bardziej stromym stokiem proksymalnym.

Podczas kolejnego etapu w wyniku zmiany reżimu termicznego w brzeżnej części lądolodu zainicjowany został proces topnienia bazalnego, który umożliwił ruch lądolodu poprzez poślizg bazalny i przekroczenie formy przez lądolód (ryc. 7C). Ponad wzgórzem rozwiną się skanalizowany drenaż subglacjalny, który rozcinał podłoże lądolodu, a wieloletnia zmarzlina uległa przypuszczalnie częściowej degradacji (Narloch i in. 2013). W ostatnim etapie wzgórze zostało pokryte warstwą gliny subglacjalnej, postępowała degradacja wieloletniej zmarzliny i kontynuowany był drenaż wód roztopowych kanałami subglacjalnymi, które rozcinały formę w podłożu lądolodu (ryc. 7D). 
A

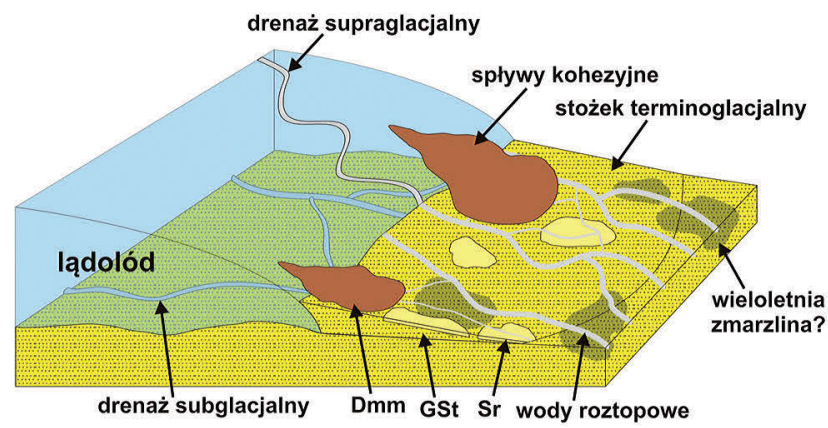

C

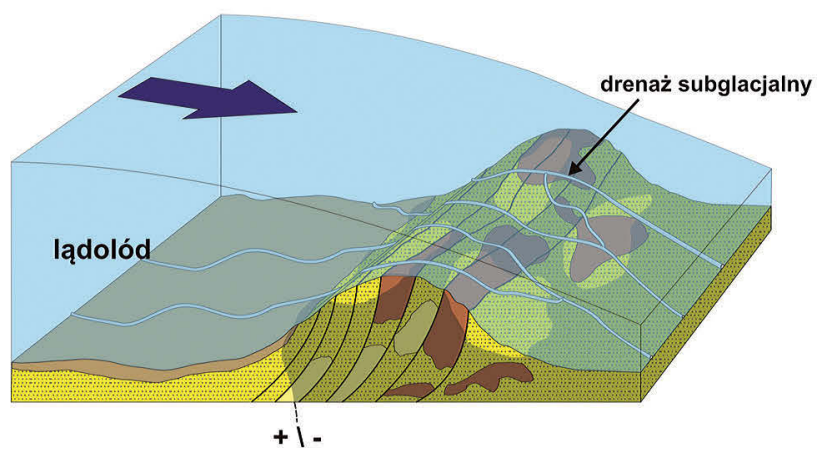

B

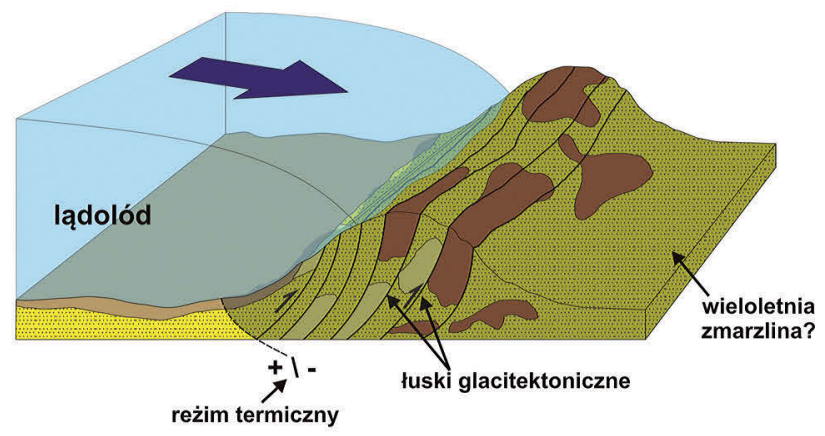

D

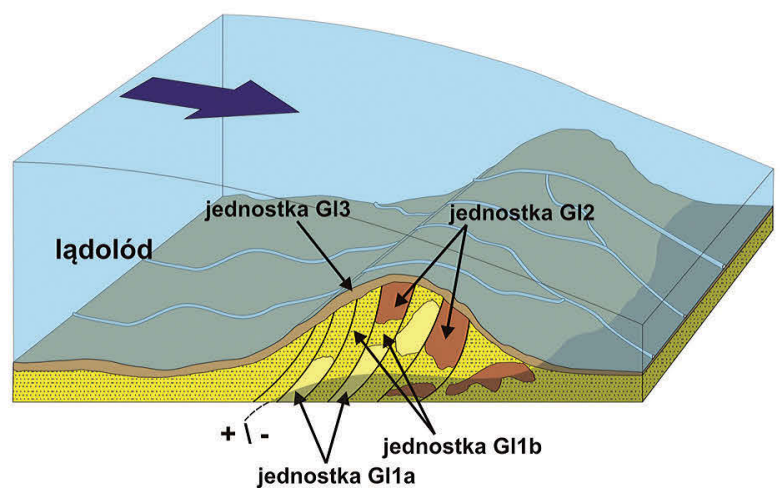

Ryc. 7. Model genetyczny sekwencji osadów oraz wzgórza w Glaznotach

A - sedymentacja zróżnicowanych facjalnie osadów w strefie marginalnej lądolodu (piaszczysto-żwirowe i piaszczyste osady jednostki Gl1 były deponowane w środowisku fluwioglacjalnym w bliskim sąsiedztwie czoła lądolodu, najprawdopodobniej w proksymalnej części stożka terminoglacjalnego, zaś osady jednostki Gl2 powstały w wyniku spływów kohezyjnych materiału różnofrakcyjnego z czoła lądolodu - glina spływowa), B - nasunięcie lądolodu i deformacja osadów jednostek G11 i G12 w warunkach wieloletniej zmarzliny przed czołem transgredującego lądolodu (powstanie moreny czołowej spiętrzonej), C - dalsza transgresja i pokrycie wzgórza przez lądolód, początek degradacji wieloletniej zmarzliny pod lodem oraz rozwój skanalizowanego drenażu subglacjalnego - erozja podłoża, D - depozycja gliny bazalnej Gl3 i zanik wieloletniej zmarzliny pod stopą lądolodu

Fig. 7. Genetic model for sediments succession and landform formation at Glaznoty

A - sedimentation of various deposits in marginal zone of the ice-sheet (sandy-gravely and sandy deposits of unit Gl1 was accumulated in a fluvioglacial environment close to the ice margin, probably on the proximal side of a terminoglacial fan while sediments of unit G12 were formed as a result of debris flow at the ice margin - flow till), B - ice-sheet advance and deformation of sediments of Gl1 and Gl2 units under the permafrost conditions in front of the advancing ice-sheet (formation of the landform as a thrust moraine), $\mathrm{C}$ - further ice-sheet advance and ice overriding, degradation of subglacial permafrost and formation of channelized subglacial drainage and erosion of the ice bed, D - deposition of basal till of unit Gl3 and decay of the permafrost under the ice sole

Uzyskane wyniki badań dowodzą, że wzgórze morenowe w Glaznotach ma złożoną genezę i było kształtowane co najmniej w trzech etapach: (1) formowanie stożka terminoglacjalnego, (2) spiętrzenie osadów przedpola lądolodu oraz (3) transformacja subglacjalna. Jest ono formą ,przejechaną", która nie została zniszczona pod lodem, a uległa jedynie modyfikacji w rezultacie drenażu subglacjalnego i depozycji gliny bazalnej. Formy tego typu, zbudowane z zaburzonego glacitektonicznie rdzenia i pokrywającej go niezgodnie warstwy gliny bazalnej, zaliczane są, według modelu zaproponowanym przez Abera (1982), do form typu cupola hills (Aber, Ber 2007).

\section{Podsumowanie i wnioski}

Możliwość występowania we współczesnej rzeźbie Garbu Lubawskiego przetrwałych form morenowych była już sygnalizowana (Gałązka, Słodkowska 2006, Gałązka i in.
2009), jednak do tej pory nie była ona poparta wynikami analiz litofacjalnych i badań struktur deformacyjnych. Dowodzą one przetrwałości wzgórz morenowych występujących na NW skłonie Garbu Lubawskiego i ich rozwoju w kilku etapach.

Wzgórze w Rożentalu, interpretowane dotąd jako spiętrzona morena czołowa (Pasierbski 1984) lub przekształcona glacitektonicznie forma szczelinowa (Rychel, Krysiak 2006, Gałązka i in. 2009), w świetle zaprezentowanych wyników jest formą złożoną o cechach przetrwałej moreny czołowej (Tylmann, Wysota 2011). Powstało ono przed ostatnim nasunięciem lądolodu na analizowanym obszarze, prawdopodobnie już $\mathrm{w}$ stadiale świecia ostatniego zlodowacenia (Tylmann 2014), a następnie ulegało transformacji w strefie subglacjalnej podczas co najmniej dwóch kolejnych transgresji ostatniego lądolodu oraz $\mathrm{w}$ warunkach peryglacjalnych $\mathrm{w}$ okresach deglacjacji Garbu Lubawskiego. Wzgórze morenowe w Rożentalu nie zostało zniszczone pod lodem, na co kluczowy wpływ 
miała przypuszczalnie obecność wieloletniej zmarzliny w strefie subglacjalnej, która oddziaływała na kształtowanie bazalnego reżimu termicznego oraz reologię osadów podłoża (większa odporność na ścinanie).

Forma typu cupola hills w Glaznotach świadczy również o przetrwałości rzeźby glacjalnej na obszarze Garbu Lubawskiego. Główny etap morfotwórczy, jakim było piętrzenie glacitektoniczne osadów przedpola lądolodu, miał miejsce najprawdopodobniej dopiero podczas transgresji ostatniego lądolodu skandynawskiego w fazie poznańskiej (Tylmann 2014). Wzgórze to przetrwało okres przykrycia lodem, ulegając jedynie modyfikacji w rezultacie drenażu subglacjalnego i depozycji gliny bazalnej. Jego przechowanie pod lądolodem można wiązać z niewielką miąższością lodu (Molewski 1999), z odpornością częściowo zamarzniętych osadów na ścinanie lub też z częstym odspajaniem stopy lądolodu, w wyniku którego naprężenie ścinające nie było przekazywane w głąb podłoża (Clark 1999).

Uzyskane wyniki skłaniają do przedstawienia kilku najistotniejszych wniosków:

- obecność wieloletniej zmarzliny na przedpolu transgredującego lądolodu oraz w strefie subglacjalnej mogła istotnie wpłynąć na przechowanie form rzeźby pod ostatnim lądolodem skandynawskim na NW skłonie Garbu Lubawskiego,

- po degradacji zmarzliny w strefie subglacjalnej w warunkach ciepłego reżimu bazalnego fluktuacje ciśnienia wód subglacjalnych skutkujące odspajaniem stopy lądolodu od podłoża sprzyjały również konserwacji form morenowych,

- konserwacja lub nieznaczna modyfikacja form rzeźby pod lodem zachodziła w strefie brzeżnej ostatniego lądolodu skandynawskiego, co dowodzi, że procesy tego typu nie ograniczały się jedynie do jego centralnej części.

\section{Podziękowania}

Badania zostały sfinansowane ze środków grantu NCN nr 2011/01/N/ST/10/05880 oraz grantu UMK nr 587-G. Autorzy dziękują dyrekcji Parku Krajobrazowego Wzgórz Dylewskich oraz właścicielom żwirowni w Rożentalu i Glaznotach za zgodę na prowadzenie badań terenowych. Dziękujemy również Recenzentom za wartościowe uwagi i sugestie, które przyczyniły się do powstania ostatecznej wersji artykułu, oraz dr. hab. P. Weckwerthowi i dr. hab. P. Molewskiemu za opiekę redakcyjną.

\section{Literatura}

Aber J.S., 1982. Model for glaciotectonism. Bulletin Geological Society of Denmark 30: 79-90.

Aber J.S., Ber A., 2007. Glaciotectonism. Developments In Quaternary Science 6. Elsevier, Amsterdam.

Astakhov V.I., Kaplyanskaya F.A., Tarnogradsky V.D., 1996. Pleistocene Permafrost of West Siberia as a Deformable Glacier Bed. Permafrost and Periglacial Processes 17: 165-191.
Bergsma B.M., Svoboda J., Freedman B., 1984. Entombed plant communities released by a retreating glacier at central Ellesmere Island, Canada. Arctic 37: 49-52.

Clark C.D., 1999. Glaciodynamic context of subglacial bedform generation and preservation. Annals of Glaciology 28: 23-32.

Clark P.U., Hansel A.K., 1989. Clast ploughing, lodgement and glacier sliding over a soft glacier bed. Boreas 18: 201-207.

Clarke G.K.C., 2005. Subglacial Processes. Annual Review of Earth and Planetary Sciences 33: 247-276.

Davis P.T., Briner J.P., Coulthard R.D., Finkel R.W., Miller G.H., 2006. Preservation of Arctic landscapes overridden by cold-based ice sheets. Quaternary Research 65: 156-163.

Dreimanis A., 1989. Tills, their genetic terminology and classification. W: R.P. Goldthwait, C.L. Matsch (red.), Genetic Classification of Glacigenic Deposits. A.A. Balkema, Rotterdam: 17-84.

Echelmeyer K., Wang Z., 1987. Direct observation of basal sliding and deformation of basal drift at sub-freezing temperatures. Journal of Glaciology 33: 83-98.

Evans D.J.A., Benn D.I. (red.), 2004. A Practical Guide to the Study of Glacial Sediments. Edward Arnold, London.

Evans D.J.A., Phillips E.R., Hiemstra J.F., Auton C.A., 2006. Subglacial till: formation, sedimentary characteristics and classification. Earth-Science Reviews 78: 115-176.

Eyles N., Eyles C.H., Miall A.D., 1983. Litofacies types and vertical profile models: an alternative approach to the description and environmental interpretation of glacial diamict and diamicte sequences. Sedimentology 30: 393-410.

French H.M., 2007. The Periglacial Environment. John Wiley \& Sons Ltd, Chichester, UK.

Gałązka D., Słodkowska B., 2006. Budowa geologiczna moreny międzylobowej Wzgórz Dylewskich. W: W. Morawski (red.), Plejstocen południowej Warmii i zachodnich Mazur na tle struktur podłoża. XIII Konferencja „Stratygrafia plejstocenu Polski”. PIG, Warszawa: $168-170$.

Gałązka D., Rychel J., Krysiak Z., 2009. Struktury glacitektoniczne a dynamika lądolodu zlodowacenia Wisły na zachodnim skłonie Garbu Lubawskiego. Prace Państwowego Instytutu Geologicznego 194: $27-34$.

Goldthwait R.P., 1960. Study of ice cliff in Nunatarssuaq, Greenland. Technical Report of the Snow, Ice and Permafrost Research Establishment 39: 1-103.

Goździk J.S., 1967. Fauchage des fentes en coin dü aux mouvements de masses sur de pentes douces. Biuletyn Peryglacjalny 16: 133-146.

Goździk J.S., 1973. Geneza i pozycja stratygraficzna struktur peryglacjalnych w środkowej Polsce. Acta Geographica Lodziensia 31.

Hätterstrand C., Stroeven A.P., 2002. A relict landscape in the centre of Fennoscandian glaciation: Geomorphological evidence of minimal Quaternary glacial erosion. Geomorphology 44: 127-143.

Hubbard B., Glasser N., 2005. Field Techniques in Glaciology and Glacial Geomorphology. Wiley, Chichester.

Hughes T., 1992. Abrupt climatic change related to unstable ice-sheet dynamics: toward a new paradigm. Global and Planetary Change 97: 203-234.

Jonsson S., 1983. On the geomorphology and past glaciation of Storöya, Svalbard. Geografiska Annaler 65A: 1-17.

Kleman J., 1992. The palimpsest glacial landscape in northeastern Sweden. Geografiska Annaler 74A: 305-325.

Kleman J., 1994. Preservation of landforms under ice sheets and ice caps. Geomorphology 9: 19-32.

Kleman J., Borgström I., 1994. Glacial land forms indicative of a partly frozen bed. Journal of Glaciology 40: 255-264.

Lawson D.E., 1979. A comparison of the pebble orientation in ice and deposits of the Matanuska Glacier, Alaska. Journal of Geology 87: 629-645.

Lawson D.E., 1982. Mobilization, movement and deposition of subaerial sediment flows, Matanuska Glacier, Alaska. Journal of Geology 90: 279-300.

Mark D.M., 1973. Analysis of axial orientation data, including till fabrics. Geological Society of America Bulletin 84: 1369-1373.

Marks L., 1979. Foreland influence on Ice-Sheet Movement during the Vistulian (Würm) Glaciation: the Case of the Lubawa Elevation 
(Mazury Lakeland). Bulletin de L'academe Polonaise des Sciences 26(3-4): 203-213.

Miall A.D., 1977. A review of the braided river environment. Earth-Science Reviews 13: 1-62.

Miall A.D., 1978. Lithofacies types and vertical profile models in braided river deposits: a summary. W: A.D. Miall (red.), Fluvial Sedimentology. Canadian Society of Petroleum Geology Memoir 5: 597-604.

Miall A.D., 1983. Glaciofluvial transport and deposition. W: N. Eyles (red.), Glacial Geology. Pergamon, New York: 168-183.

Molewski P., 1999. Rynna Gopła - problem jej genezy i roli w odpływie wód roztopowych podczas zlodowacenia vistuliańskiego. Studia Societatis Scientarium Torunensis, Sectio C (Geographia et Geologia) $\mathrm{X}$.

Molewski P., 2007. Neotektoniczne i glacidynamiczne uwarunkowania wykształcenia plejstocenu Wysoczyzny Kujawskiej. Wydawnictwo Naukowe UMK, Toruń.

Munro-Stasiuk M.J., 2000. Rhythmic till sedimentation: evidence for repeated hydraulic lifting of a stagnant ice mass. Journal of Sedimentary Research 70: 94-106.

Murton J.B., 2007. Ice wedges and ice wedge casts. W: S.A. Elias (red.), Encyclopedia of Quaternary Sciences. Elsevier: 2153-2170.

Murton J.B., French H.M., 1993. Thaw modification of frost-fissure wedges, Richards Island, Pleistocene Mackenzie Delta, western Canadian Arctic. Journal of Quaternary Science 8: 185-196.

Murton J.B., Worsley P., Goździk J., 2000. Sand veins and wedges in cold aeolian environments. Quaternary Science Reviews 19: 899922 .

Mycielska-Dowgiałło E., 1998. Znaczenie interpretacyjne brył piaszczystych i żwirowych w osadach fluwialnych i fluwioglacjalnych. W: E. Mycielska-Dowgiałło (red.), Struktury sedymentacyjne i postsedymentacyjne w osadach czwartorzędowych i ich wartość interpretacyjna. Wydział Geografii i Studiów Regionalnych, Uniwersytet Warszawski, Warszawa: 115-120

Narloch W., Wysota W., Piotrowski J.A., 2013. Sedimentological record of subglacial conditions and ice sheet dynamics of the Vistula Ice Stream (north-central Poland) during the Last Glaciation. Sedimentary Geology 293: 30-44.

Pasierbski M., 1984. Struktura moren czołowych jako jeden ze wskaźników sposobu deglacjacji ostatniego zlodowacenia w Polsce. Wydawnictwo UMK, Toruń.

Piotrowski J.A., Tulaczyk S., 1999. Subglacial conditions under the last ice sheet in northwest Germany: ice-bed separation and enhanced basal sliding? Quaternary Science Reviews 18: 737-751.

Piotrowski J.A., Hermanowski P., Piechota A.M., 2009. Meltwater discharge through the subglacial bed and its land-forming consequences from numerical experiments in the Polish lowland during the last glaciation. Earth Surface Processes and Landforms 34: 481-492.

Pisarska-Jamroży M., Zieliński T., 2012. Specific erosional and depositional processes in a Pleistocene subglacial tunnel in the Wielkopolska region, Poland. Geografiska Annaler 94A: 429-443.

Roman M., 2010. Rekonstrukcja lobu płockiego w czasie ostatniego zlodowacenia. Acta Geographica Lodzensia 96: 1-171.
Roman M., 2012. Rzeźba palimpsestowa w krajobrazie polodowcowym na przykładzie wzgórza morenowego Izbicy Kujawskiej. Acta Geographica Lodzensia 100: 147-160.

Rychel J., Krysiak Z., 2006. Forma szczelinowa w Rożentalu: glacitektonika, sedymentacja, stratygrafia. W: W. Morawski (red.), Plejstocen południowej Warmii i zachodnich Mazur na tle struktur podłoża. XIII Konferencja „Stratygrafia plejstocenu Polski”, PIG, Warszawa: $165-167$.

Shaw J., 1979. Genesis of the Sveg tills and Rogen moraines of central Sweden: a model of basal melt-out. Boreas 8: 409-426.

Shaw J., 1982. Melt-out till in the Edmonton area, Alberta, Canada. Canadian Journal of Earth Sciences 19: 1548-1569.

Szuman I., Ewertowski M., Kasprzak L., 2013. Thermo-mechanical facies representative of fast and slow flowing ice sheets: the Weichselian ice sheet, a central west Poland case study. Proceedings of the Geologists' Association 124: 818-833.

Terpiłowski S., 2003. Nowa propozycja zapisu genezy osadów glacimarginalnych. W: M. Harasimiuk, S. Terpiłowski (red.), Analizy sedymentologiczne osadów glacigenicznych. Kom. Bad. Czwartorzędu PAN, UMCS, Lublin: 81-93.

Tylmann K., 2014. Dynamika procesów glacjalnych na obszarze Garbu Lubawskiego podczas ostatniego zlodowacenia. MS, Archiwum UMK, Toruń

Tylmann K., Wysota W., 2011. Geneza i transformacja rzeźby morenowej w północno-zachodniej części Garbu Lubawskiego (Polska północna). Przegląd Geologiczny 59: 739-750.

van der Wateren D.F.M., 1985. A model of glacial tectonics, applied to the ice-pushed ridges in the Central Netherlands. Bulletin Geological Society of Denmark 34: 55-74.

Waller R., Murton J.B., Whiteman C., 2009. Geological evidence for subglacial deformation of Pleistocene permafrost. Proceedings of the Geologists' Association 120: 155-162.

Waller R., Murton J.B., Kristensen L., 2012. Glacier-permafrost interactions: processes, products and glaciological implications. Sedimentary Geology 255/256: 1-28.

Wysota W., 2002. Stratygrafia i środowiska sedymentacji zlodowacenia wisły w południowej części dolnego Powiśla. Wydawnictwo UMK, Toruń.

Wysota W., 2007. Successive subglacial depositional processes as interpreted from basal tills in the Lower Vistula valley (N Poland). Sedimentary Geology 193: 21-31.

Zieliński T., 1992. Moreny czołowe Polski północno-wschodniej - osady i warunki sedymentacji. Wydawnictwo UŚ, Katowice.

Zieliński T., 1998. Litofacjalna identyfikacja osadów rzecznych. W: E. Mycielska-Dowgiałło (red.), Struktury sedymentacyjne i postsedymentacyjne $\mathrm{w}$ osadach czwartorzędowych i ich wartość interpretacyjna. Wydział Geografii i Studiów Regionalnych, Uniwersytet Warszawski, Warszawa: 195-253.

Zieliński T., van Loon A.J., 1999. Subaerial terminoglacial fans I. A semi-quantitative sedimentological analysis of the proximal environment. Geologie en Mijnbouw 78: 1-15.

Zieliński T., van Loon A.J., 2000. Subaerial terminoglacial fans III. Overview of sedimentary characteristics and depositional model. Geologie en Mijnbouw 79: 93-107. 